An i n vitro system to char acterize prost ate cancer progressi on i dent i fi ed si gnal ing requi red for sel $f$-renewal

\begin{tabular}{|l|l|}
\hline 著者 & $\begin{array}{l}\text { Sal ah Nhammed, N shi mot o Yuuki, Kohno Susum, } \\
\text { Kondoh At sushi, K t aj i ma Shunsuke, Mr anaka } \\
\text { Hayat o, Ni shi uchi Takum, I br ahi m Ahned, } \\
\text { Yoshi da Aki yo, Takahashi Chi aki }\end{array}$ \\
\hline $\begin{array}{l}\text { j our nal or } \\
\text { publ i cat i on ti tl e }\end{array}$ & Mbl ecul ar Car ci nogenesi s \\
\hline vol une & 55 \\
\hline number & 12 \\
\hline page r ange & 1974 1989 \\
\hline year & $2016-12-01$ \\
\hline URL & ht t p: //hdl . handl e. net /2297/46761 \\
\hline
\end{tabular}




\title{
An in vitro system to characterize prostate cancer progression identified signaling required for self-renewal
}

Mohammed Salah ${ }^{1,2}$, Yuuki Nishimoto ${ }^{2}$, Susumu Kohno ${ }^{2}$, Atsushi Kondoh ${ }^{2}$, Shunsuke Kitajima $^{2,3}$, Hayato Muranaka ${ }^{2}$, Takumi Nishiuchi ${ }^{4}$, Ahmed Ibrahim ${ }^{1,5}$, Akiyo Yoshida ${ }^{2,6}$ and Chiaki Takahashi ${ }^{2, *}$

${ }^{1}$ Biochemistry Department, Faculty of Veterinary Medicine, South Valley University, Qena, 83523, Egypt. ${ }^{2}$ Division of Oncology and Molecular Biology, Cancer Research Institute, Kanazawa University, Japan. ${ }^{3}$ Department of Medical Oncology, DanaFarber Cancer Institute Boston, MA02215, USA. ${ }^{4}$ Division of Functional Genomics, Advanced Science Research Center, Kanazawa University, Kanazawa, Ishikawa 9200934, Japan. ${ }^{5}$ Poultry Diseases Department, Faculty of Veterinary Medicine, South Valley University, Qena, 83523, Egypt. ${ }^{6}$ Deperment of Cellular Transplantation Biology, Graduate School of Medical Science, Kanazawa University, Kanazawa, Ishikawa 920-8641, Japan.

*Correspondence: chtakaha@staff.kanazawa-u.ac.jp

\begin{abstract}
Mutations in $R B$ and PTEN are linked to castration resistance and poor prognosis in prostate cancer. Identification of genes that are regulated by these tumor suppressors in a context that recapitulates cancer progression may be beneficial for discovering novel therapeutic targets. Although various genetically engineered mice thus far provided tumor models with various pathological stages, they are not ideal for detecting dynamic changes in gene transcription. Additionally, it is difficult to achieve an effect specific to tumor progression via gain of functions of these genes. In this study, we developed an in vitro model to help identify $R B$ - and PTEN-loss signatures during the malignant progression of

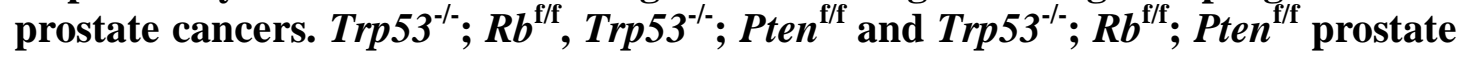
epithelial cells were infected with AD-LacZ or AD-Cre. We found that deletion of $\boldsymbol{R} b$, Pten or both stimulated prostasphere formation and tumor development in immune-compromised mice. The GO analysis of genes affected by the deletion of $\boldsymbol{R b}$ or Pten in $\operatorname{Trp}^{-/-}$prostate epithelial cells identified a number of genes encoding cytokines, chemokines and extracellular matrix remodeling factors, but only few genes related to cell cycle progression. Two genes (II-6 and Lox) were further analyzed. Blockade of Il-6 signaling and depletion of Lox significantly attenuated prostasphere formation in 3D culture, and in the case of IL-6, strongly suppressed tumor growth in vivo. These findings suggest that our in
\end{abstract}


vitro model may be instrumental in identifying novel therapeutic targets of prostate cancer progression, and further underscore IL-6 and LOX as promising therapeutic targets.

Key words: $R b$; Pten; Prostasphere; Prostate cancer

\begin{abstract}
Abbreviations $R B$, retinoblastoma tumor suppressor gene; PTEN, phosphatase and tensin homolog gene; $\mathrm{AD}$, adenovirus; GO, gene ontology; IL-6, interleukin 6; Lox, lysyl oxidase
\end{abstract}

\title{
INTRODUCTION
}

Early stage prostate cancer can be effectively treated by androgen deprivation therapy, however late stage tumors become hormone-refractory and have a poor prognosis. The current therapeutic treatments for late stage prostate cancer are often ineffective, thus allowing for relapse and metastasis [1]. It has been reported that $25 \%$ to $50 \%$ of prostate cancer cases are characterized by $R B$ loss of heterozygosity [2,3]. Furthermore, more than $70 \%$ of metastatic and castration resistant cases appear to be pRB-negative [4]. The Trp53 mutation is thought to occur at an early stage during prostate cancer development [5]. The combination of the Trp53 mutation and loss of $R b$ in the mouse prostate gland results in highly aggressive and metastatic prostate carcinomas [6]. Therefore, a more detailed molecular characterization of prostate cancer progression might be achieved by determining the $R B$ loss signature in the Trp53-deficient background.

Monoallelic deletion of PTEN occurs in approximately $70 \%$ of human prostate cancers [7]. Biallelic loss of PTEN and an associated increase in AKT phosphorylation is often identified in metastatic and advanced prostate cancers [4]. The loss of PTEN in prostate gland epithelial cells generates hyperplasia, which then progresses to invasive and hormone-refractory cancer when combined with the loss of Trp53 [8,9]. Additionally, the origin of primary prostate cancer, which gives rise to lethal metastatic clones, is often characterized by a mutation in Trp53 and loss of PTEN [10]. Therefore, in addition to RB loss, PTEN loss in a Trp53-deficient background may also facilitate characterization of the malignant progression in prostate cancer.

In the current study, we established in vitro models to determine the $R b$ and Pten loss gene signatures in $\operatorname{Trp}_{53}{ }^{-/-}$mouse prostate epithelial cells cultured under 2D conditions. In comparison to $\operatorname{Trp53} 3^{+/+}$cells, $\operatorname{Trp} 53^{-/-}$prostate epithelial cells, regardless of $R b$ or Pten status, more easily adapt to $2 \mathrm{D}$ primary culture conditions. In addition, they maintained a low level of androgen receptor (AR) expression as well as some features of basal-like cells. However, when injected into KSN athymic mice, Trp $53^{-/-}$prostate epithelial cells lacking $R b$ and Pten exhibited multiple characteristics of luminal type prostate cancer. Human prostate cancers typically have a luminal phenotype, and some reports have indicated that basal cells could be cell-of-origin of luminal type prostate cancers [11-13]. Therefore, we believe our in vitro models mimic the carcinogenic processes of human prostate cancer development.

Our prostate cancer development model provides a system to examine signatures of 
tumor suppressor loss-of-function in the context of tumor progression. The signatures in cells with $R b$ or Pten loss-of-function contained relatively few genes encoding cell cycle-related proteins, which is consistent with the moderate impact of deletions in $R b$ and Pten on cell proliferation. However, a number of genes encoding cytokines, chemokines, and proteins implicated in extracellular remodeling were identified. The results of this study suggest that our in vitro models may be instrumental in identifying key molecules that control malignant behaviors of prostate cancer cells.

\section{MATERIALS AND METHODS}

\section{Mice}

Trp53-knockout mice [14] were obtained from RIKEN BRC (\#CDB0001K). C57BL/6 mice were purchased from Japan SLC. $R b$-floxed $\left(R b^{f / f}\right)$ mice [15] were obtained from NCI Mouse Repository (\#01XC1) under the permission by Dr. A Berns. Pten-floxed $\left(\right.$ Pten $\left.^{f / f}\right)$ mice [16] were obtained from Kyushu University under the permission by Dr. A Suzuki. KSN athymic mice were purchased from SLC Japan. Animals were handled in accordance with the guidelines of Kanazawa University.

\section{Genotyping}

Mouse genomic DNA was isolated from cut tails following overnight digestion at $55^{\circ} \mathrm{C}$ in buffer containing $0.1 \mathrm{M}$ Tris- $\mathrm{HCl}$ (pH 8.0), $5 \mathrm{mM}$ EDTA, $0.25 \mathrm{M} \mathrm{NaCl}, 0.2 \%$ SDS and $100 \mu \mathrm{g} / \mathrm{mL}$ proteinase $\mathrm{K}$, followed by heat inactivation. PCR was performed using the primer pairs to distinguish the $R b^{f / f}\left(\mathrm{~F} ; 5^{\prime}\right.$ GGCGTGTGCCATCAAT $3^{\prime}$ and R; 5' AACTCAAGGGAGACCTG 3'), Trp53 (F; 5' GTTATGCATCCATACAGTACA $3^{\prime}$ and R; 5' CAGGATATCTTCTGGAGGAAG 3') and Pten ${ }^{\text {f/f }}$ (F; 5' CTCCTCTACTCCATTCTTCCC $3^{\prime}$ and R; 5' ACTCCCACCAATGAACAAAC $3^{\prime}$ ). PCR conditions were as follows: $R b^{\text {f/f; }} 95^{\circ} \mathrm{C} 2 \mathrm{~min},\left(95^{\circ} \mathrm{C}\right.$ for $30 \mathrm{~s}, 58{ }^{\circ} \mathrm{C}$ for $30 \mathrm{~s}$, $72{ }^{\circ} \mathrm{C}$ for $\left.50 \mathrm{~s}\right) \times 30$ cycles, $72{ }^{\circ} \mathrm{C}$ for $1 \mathrm{~min}$, Trp53; $94^{\circ} \mathrm{C} 5 \mathrm{~min},\left(94{ }^{\circ} \mathrm{C}\right.$ for $30 \mathrm{~s}$, $57{ }^{\circ} \mathrm{C}$ for $30 \mathrm{~s}, 72{ }^{\circ} \mathrm{C}$ for $\left.2 \mathrm{~min}\right) \times 30$ cycles, $72{ }^{\circ} \mathrm{C} 5 \mathrm{~min}, \mathrm{Pten}^{\mathrm{f} / f}$; $95^{\circ} \mathrm{C}$ for $15 \mathrm{~min}$, (95 ${ }^{\circ} \mathrm{C}$ for $1 \mathrm{~min}, 58^{\circ} \mathrm{C}$ for $1 \mathrm{~min}, 72^{\circ} \mathrm{C}$ for $1 \mathrm{~min}$ ) x 40 cycles, $72^{\circ} \mathrm{C}$ for $10 \mathrm{~min}$.

\section{Primary Culture of Prostate Epithelial Cells}

Whole prostate gland including anterior, dorsolateral and ventral lobes were harvested from 8 - 12 weeks old Trp53 ${ }^{-/-} ; R^{f / f}$, Trp53 ${ }^{-/-}$; Pten $^{f / f}$ or ${\operatorname{Trp} 53^{-/-} ; \text {Rb }^{f / f} \text {; Pten }}^{f / f}$ male mice, and digested with one part 10x Collagenase/Hyaluronidase (\#07912, STEMCELL Technologies) and nine parts DMEM/F-12 (\#36254, STEMCELL Technologies) supplemented with 5\% FBS (\#SH30079, HyClone) for 3 hrs at $37^{\circ} \mathrm{C}$. The resultant organoids were further digested in 0.25\% trypsin-EDTA (1 hr), $5 \mathrm{mg} / \mathrm{ml}$ Dispase and $100 \mu \mathrm{g} / \mathrm{ml}$ DNase I (1 min), and then filtered through a $40 \mu \mathrm{m}$ cell strainer. Lineage positive hematopoietic, endothelial and fibroblast cells (CD45 ${ }^{+}$; $\mathrm{CD}^{+} 1^{+}$; Ter119 ${ }^{+}$; BP-1 ${ }^{+}$) were removed using EasySep Mouse Epithelial Cell Enrichment Kit (\#19758, STEMCELL Technologies). The resulting epithelial cells were maintained in FBS-free ProstaCult ${ }^{\mathrm{TM}}$ Medium (\#05640, STEMCELL Technologies) supplemented with $10 \mathrm{ng} / \mathrm{mL}$ recombinant human bFGF (rh bFGF) (PeproTech), 10 ng/mL recombinant human EGF (rh EGF) (PeproTech) and $4 \mu \mathrm{g} / \mathrm{mL}$ Heparin (\#07980, STEMCELL Technologies), and plated onto collagen coated dishes 
(Iwaki).

\section{Adenovirus}

HEK293 cells were maintained in $\alpha$ modified Eagle's medium ( $\alpha$ MEM) (\#135-15175, WAKO) supplemented with 10\% FBS. After reaching $80 \%$ confluence in a D100 dish, HEK293 cells were transduced with AxCANCre (RDB01748, RIKEN BRC) (ADCre) or AxCALNLNZ (RDB01750, RIKEN BRC) (AD-LacZ). When the cells detached completely after a few days, suspended cells were harvested, sonicated and centrifuged at $9,400 \times \mathrm{g}$ at $4{ }^{\circ} \mathrm{C}$. Then the supernatants were collected, passed through a $0.45 \mu \mathrm{m}$ filter and used as adenovirus particles.

\section{Immunoblotting}

Total cell lysates were prepared for immunoblotting as described previously [17]. Used antibodies were to: Rb (\#554136, BD Biosciences), Pten (\#9559, Cell Signaling Technology), AR (N-20)(sc-816, Santa Cruz), CK18 (\#65028, Progen Biotechnik), CK5 (\#PRB-160P, Covance), $\alpha$-Tubulin (\#CP06, Calbiochem), phospho-Akt (\#9271, Cell Signaling Technology), phospho-Stat3 (\#9145, Cell Signaling Technology), Stat3 (\#9139, Cell Signaling Technology), phospho-Erk1/2 (\#9102, Cell Signaling Technology), phospho-Src family (\#6943, Cell Signaling Technology) and phosphoFAK (\#611722, BD Biosciences).

\section{Quantitative Proliferation Assay}

$0.75 \times 10^{5}$ cells were plated in 6-well collagen-coated plate. After 3 day incubation, the total number of cells in each well was counted using a particle counter (Coulter Counter Z1, Beckman Coulter), and $0.75 \times 10^{5}$ cells were replated onto the 6-well collagen-coated plate. This procedure was repeated every 3 days for 10 passages and cumulative cell number was calculated from each total cell number.

\section{BrdU Incorporation Assay}

$2 \times 10^{5}$ cells were plated onto $0.1 \%$ collagen-coated slides in 6-well plate. After $24 \mathrm{hr}$ incubation, cultured cells were incubated with $10 \mu \mathrm{M} \mathrm{BrdU}$ for $20 \mathrm{~min}$. Cells were stained using the BrdU Labeling and Detection Kit l (\#11 296736 001, Roche) according to the manufacturer's instruction. Cell nuclei were counterstained with DAPI, observed on a fluorescence microscopy and analyzed by BZ analysis software on BZ-9000 (Keyence) using hybrid cell counting module.

\section{Colony Formation Assay}

$6 \times 10^{3}$ prostate epithelial cells were plated in a collagen-coated 6-well plate. After 14 day incubation, resultant colonies were stained with a modified Giemsa solution.

\section{RT-qPCR}

Total RNA was isolated from cultured cells by using TRIzol (\#15596018, Life Technologies) according to the manufacturer's instructions. The purified total RNA was reverse-transcribed at $37{ }^{\circ} \mathrm{C}$ in the presence of random hexamer primers, and reaction products were diluted with DEPC-treated water. PCR was performed in a reaction mixture $(20 \mu \mathrm{l})$ containing cDNA solution $(1 \mu \mathrm{l}), 1 \mathrm{x}$ TaqMan Gene 
Expression Master Mix and TaqMan probe $(1 \mu \mathrm{l})$. The following thermal profile was used for PCR amplification: 1 cycle of $94^{\circ} \mathrm{C}$ for $1 \mathrm{~min}$ and 50 cycles of $95^{\circ} \mathrm{C}$ for $5 \mathrm{sec}$, and $60^{\circ} \mathrm{C}$ for $30 \mathrm{sec}$. For the quantitative determination of gene expression, the accumulation of PCR products was measured directly by monitoring fluorescence intensity on Light cycler 480 Instruments II (Roche). Quantitative PCR of total RNA was performed as described previously [18] using following Taqman probes to: Actb (Mm00607939_s1), Il-6 (Mm00446190_m1), Lif (Mm00434762_g1), Cxcl5 (Mm00436451_g1), Rb1 (Mm00485586_m1), Gapdh (Mm99999915-g1), Ccl5 (Mm01302427_m1), Lox (Mm00495386_m1), Nanog (Mm02019550_s1) and Oct4 (Mm03053917_g1).

\section{Soft Agar Assay}

$1 \times 10^{5}$ single cells were suspended in ProstaCult ${ }^{\mathrm{TM}}$ media and $0.33 \%$ agar, and then mounted over a bottom layer of solidified $\alpha$ MEM containing $10 \% \mathrm{FBS}$ and $0.8 \%$ agar. After 4 weeks incubation, colonies were observed under the inverted phase contrast microscopy, and analyzed by BZ analysis software on BZ-9000 using hybrid cell counting module.

\section{Prostasphere Assay}

Cells cultured under 2D conditions (monolayer) were dissociated with trypsin-EDTA, filtered through a $40 \mu \mathrm{m}$ cell strainer, and then inoculated into $1 \%$ methylcellulosecontaining aMEM supplemented with B27 (Life Technologies), $10 \mathrm{ng} / \mathrm{ml}$ rh EGF (PeproTech) and $10 \mathrm{ng} / \mathrm{ml} \mathrm{rh}$ bFGF (PeproTech), without serum, at a density of $5 \mathrm{x}$ $10^{4}$ cells on 6-well-type ultra-low attachment plate (EZ-BindShut II, AGC Techno Glass). After 14 days incubation, spheres were observed under the inverted phase contrast microscopy, and analyzed by BZ analysis software on BZ-9000 (Keyence) using hybrid cell counting module.

\section{Xenograft Assay}

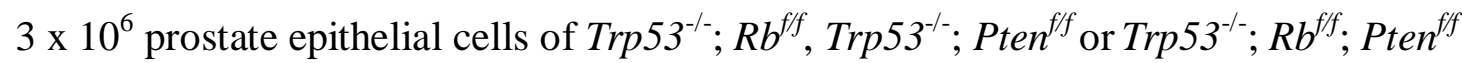
background that were infected with $\mathrm{AD}$-LacZ or $\mathrm{AD}$-Cre were mixed with the same volume of Matrigel (BD Biosciences) and injected subcutaneously into 10 male KSN athymic mice (6-8 weeks old). Number of mice bearing tumors and their time onset were recorded.

\section{Histopathology and Immunohistochemistry}

The specimens from the anterior prostate and subcutaneous tumor tissue were rapidly excised, which were fixed in 4\% paraformaldehyde in phosphate buffered saline (PBS). Paraffin sections of $5 \mu \mathrm{m}$ were prepared and stained with Hematoxylin and Eosin (H\&E) stain for histopathological observation or stained with monoclonal antibody to Ki-67 (clone D3B5; Cell Signaling Technology), AR (N-20)(sc-816, Santa Cruz), CK18 (\#65028, Progen Biotechnik), CK5 (\#PRB-160P, Covance), and Ecadherin (sc-7870, Santa Cruz), and counterstained with hematoxylin.

\section{Microarray Analysis}

Total RNA was extracted using the RNeasy Mini Kit (\#74106, Qiagen, Valencia, CA, 
USA) according to the manufacturer's instructions. Total RNA quality was detected using the RNA 6000 Nano Lab Chip Kit (Bio analyzer 2100, Agilent Technologies, Santa Clara, CA, USA). The microarray analysis of $\operatorname{Tr} p 53^{-/-} ; R b^{f / f}$ series prostate epithelial cells was performed with a Whole Mouse Genome Microarray $4 \times 44 \mathrm{~K}$ v2 Microarray (\#26655, Agilent Technologies). Data were analyzed by Gene Spring 12.6.1-GX-PA (Agilent Technologies). The raw data are available in Gene Expression Omnibus (GEO) database (GSE68903). $R b^{f / f} \operatorname{Trp}^{\mathrm{s}} 3^{-/-} \mathrm{Pten}^{f / f}$ series microarray was performed with a Sureprint G3 Mouse GE 8 X 60k (\#28005, Agilent Technologies). The fluorescence intensity was measured by the G2505C Microarray Scanner (Agilent). Data were analyzed by Gene Spring 13.0-GX-PA (Agilent Technologies). The raw data are available in Gene Expression Omnibus (GEO) database (GSE68904).

\section{RNA Interference}

MISSION TRC shRNA target sets for mouse Il-6 (TRCN0000067548 and TRCN0000067552), mouse Lox (TRCN0000321012, TRCN00000011850 and TRCN0000011852) and negative control (Non-target; SHC002) were purchased from Sigma-Aldrich. Generation and infection of lentivirus were performed according to the manufacturer's instruction.

\section{Gene Set Enrichment Analysis}

GSEA (http://www.broadinstitute.org/gsea/index.jsp) was performed on Signal-toNoise metrics using gene sets obtained from "C2 all v4.0" and "C3 all v4.0" gene sets.

\section{Pathway Analysis}

It was established on Gene Ontology (GO) and Kyoto Encyclopedia of Genes and Genomes (KEGG) analysis systems supported by DAVID v6.7.

\section{Reagents}

The following reagents were used: AKT inhibitor LY294002 (\#9901S, Cell Signaling Technology), E2F inhibitor HLM006474 (\#324461, Millipore), IKK-2 Inhibitor IV (\#401481, Millipore), Stattic (\#sc-202818, Santa Cruz), anti-mouse Il-6 receptor alpha antibody (\#AF1830, R\&D Systems), goat-IgG (\#005-000-003, Jackson ImmunoResearch), and recombinant mouse Il-6 (\#406-ML-005, R\&D Systems).

\section{Statistical Analysis}

Results were expressed as means \pm standard deviation. Data were analyzed statistically using unpaired Student's $t$-test between two groups or one-way ANOVA with Tukey Comparison Test as a post test among more than three groups using the computer statistics Prism 5.0 package (GraphPad Software, Inc, San Diego, CA, USA). $P$ values less than 0.05 were considered statistically significant. $* P<0.05$, $* * P<0.01$ and ${ }^{* * *} P<0.001$.

\section{RESULTS}

Establishment of $\operatorname{Trp} 53^{-/-}$prostate epithelial cells with varied $\boldsymbol{R} \boldsymbol{b}$ and Pten status 
To establish in vitro models to determine $R b$ and Pten loss signatures during prostate cancer development, we made primary cultures of mouse prostate epithelial cells of the following genotypes: Trp53 $3^{-/-} ; R^{f f f}$, Trp53 ${ }^{-/-} ;$Pten $^{f / f}$ and Trp53 ${ }^{-/-} ;$Rb $^{f / f} ;$ Pten $^{f / f}$. The urogenital organs, including seminal vesicles, prostate gland, urinary bladder and urethra, were separated together from each mouse, and then whole prostate gland was extracted according to a surgical procedure previously described [19] (Fig. 1A-a, b). The histology of the anterior prostate cross sections assessed by hematoxylin and eosin (H\&E) staining was compatible with that of the prostate gland (Fig. 1A-c). Prostate cells were then isolated by digesting a mixture of anterior, dorsolateral, and ventral lobes with multiple enzymes. After removing lineage-positive hematopoietic, endothelial and fibroblastic cells (CD45 ${ }^{+}, \mathrm{CD}_{3} 1^{+}$, Ter $119^{+}$, and $\left.\mathrm{BP}-1^{+}\right)$, the resultant cells were cultured in serum-free ProstaCult $^{\mathrm{TM}}$ Medium supplemented with recombinant human (rh) bFGF and rh EGF. The serum-free condition prevents growth of stromal cells (Fig. 1A-d).

Successful deletion of $R b$ and/or Pten in Trp53-null cells after infection with adenovirus carrying Cre recombinase (AD-Cre) was confirmed using RT-qPCR and an immunoblotting assay (Fig. 1B and C). Adenovirus carrying LacZ (AD-LacZ) was used as a control. Cells from each of the genotypes were then passaged for 2-3 times until they became homogenous. Next, the cells were characterized by examining cell lineage markers. Immunoblotting analysis revealed that cells from all genotypes exhibited only a weak signal for the androgen receptor (AR) regardless of the $R b$ and Pten status (Fig. 1C). Immunofluorescent analysis of AR detected no strong signal in any of our prostate cells; however, it did detect a strong signal in a well-known ARpositive human prostate cancer cell line, LNCap (data not shown). We therefore concluded that our prostate cells were not expressing sufficient level of AR to be functional during our cultivation. Moreover, all genotypes of prostate cells tested strongly expressed cytokeratin 5 (CK5), (a basal marker), but expressed CK18, (a luminal marker) only weakly (Fig. 1C). These observations suggest that our prostate cells cultured under $2 \mathrm{D}$ condition exhibited the features of basal type cells $\left(\mathrm{CK} 5^{+}\right.$: CK18; $\mathrm{AR}^{\mathrm{LOW}}$ ).

The cumulative cell growth was assessed in $\operatorname{Trp53}{ }^{--} ; R b^{f / f}$ infected with AD-LacZ and

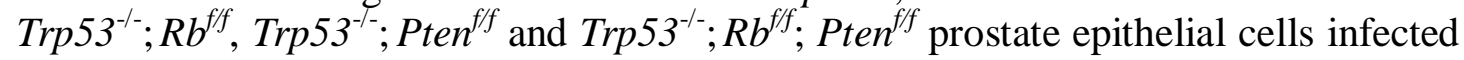
with AD-Cre. Additional deletion of $R b$ and Pten moderately stimulated cell growth; this was more evident when both genes were deleted (Fig. 1D). The stimulation of cell growth was also assessed by BrdU incorporation (Fig. 1E). We also examined the growth of Trp53-positive prostate cells; however, these cells did not survive during the cumulative cell proliferation assay (data not shown). These findings suggest that the loss of function of Trp53 significantly increased the ability of prostate epithelial cells to survive under ProstaCult ${ }^{\mathrm{TM}}$ culture conditions, and the additional loss of $R b$ and Pten moderately stimulated cell proliferation in vitro. We observed that these cells survived up to 10 passages without showing sign of crisis (Fig. 1D). In addition, these cells formed colonies when $6 \times 10^{3}$ cells were cultured in a $60 \mathrm{~mm}$ regular dish (Fig. $1 F)$. However, no colonies were generated from any lines when less than $1 \times 10^{3}$ cells were plated (data not shown). These findings indicate that all genotypes of $\operatorname{Trp} 53^{-/-}$ prostate epithelial cells examined were similarly fitted to growth in ProstaCult ${ }^{\mathrm{TM}}$ culture condition. 


\section{Prostasphere formation by $\operatorname{Trp} 53^{-/-}$prostate epithelial cells with varied $R \boldsymbol{b}$ and Pten status}

Malignant behaviors of cancer cells are often explained by their persistent selfrenewal activity. We compared prostasphere-forming activities in different genotypes of prostate epithelial cells. Trp53-null prostate epithelial cells were able to form prostaspheres to some degree. This ability was significantly increased by the deletion of $R b$ or Pten, and an even greater increase was observed when both $R b$ and Pten were deleted (Fig. 2A). Expression of Nanog and Oct4 were significantly induced in prostaspheres when compared to cells cultured under monolayer conditions, and the amount of induction correlated with prostasphere-forming activities (Fig. 2B). Interestingly, Oct4 increased in Trp53 ${ }^{-/-}$prostate epithelial cells after deletion of $R b$ and Pten even under monolayer conditions, implying that the status of $R b$ and Pten cooperatively and directly influenced expression of Oct4 (Fig. 2B).

\section{Tumorigenicity by $\operatorname{Trp}^{-3^{--}}$prostate epithelial cells requires inactivation of Rb or Pten}

Colony forming activity of prostate epithelial cells in soft agar was correlated with prostasphere-forming activity (Fig. 3A). Trp53 ${ }^{-/}$prostate epithelial cells without the deletion of $R b$ or Pten were not able to initiate a tumor in KSN athymic mice during 12 months of observation after subcutaneous inoculation (Fig, 3B). However, the deletion of $R b$ or Pten enabled Trp53/- prostate epithelial cells to propagate in KSN athymic mice. Simultaneous deletion of $R b$ and Pten enabled Trp53 ${ }^{-/-}$cells to develop a visible tumor much earlier (Fig, 3B). H\&E staining of a tumor derived from Trp53 ${ }^{-1-}$ cells simultaneously lacking $\mathrm{Rb}$ and Pten detected cells with highly atypical nucleus with a very high N/C ratio (Fig. 3C). These cells highly expressed Ki-67 (Fig. 3D). These findings indicate that $\mathrm{Rb}$ or Pten loss-of-function is required for Trp53 ${ }^{-/-}$ prostate epithelial cells to develop a tumor in KSN athymic mice. Next, we further analyzed the tumor phenotype of $\operatorname{Tr} 553^{-/-}, R^{f / f}$, Pten $^{f / f}$ prostate epithelial cells infected with AD-Cre. Importantly, tumors derived from these cells exhibited various features of luminal type cells, which are characterized by positive expression of AR, CK18 and E-cadherin and decreased expression of CK5 (Fig. 3E). This result clearly indicated that $\operatorname{Trp}_{53^{-/}} ; \mathrm{Rb}^{f / f}$; Pten ${ }^{f / f}$ prostate epithelial cells infected with AD-Cre underwent basal-to-luminal conversion during propagation in athymic mice. Therefore, we concluded that our prostate epithelial cell models can mimic human prostate carcinogenesis.

\section{Genes affected by $R b$ or $R b$-Pten status in $\operatorname{Trp} 53^{-/-}$prostate epithelial cells}

To identify genes that may be mechanistically involved in the malignant progression of prostate cancers, we measured gene transcripts using microarray analysis. The GO analysis of genes upregulated by the deletion of $R b$ in $\operatorname{Trp} 53^{-/-}$prostate epithelial cells identified cytokines, chemokines, inflammatory response, and extracellular space genes (Table 1). The same analysis of $\operatorname{Tr} p 53^{-/-}$prostate epithelial cells that lacked both $R b$ and Pten resulted in similar gene ontology categories (Table 2). Clustering of 77 genes affected by the Rb-Pten status in $\operatorname{Trp} 53^{-/-}$prostate epithelial cells with the 
highest level of significance ( $\mathrm{N}=4$ in each setting) showed approximately $40 \%$ of the affected genes were upregulated and the remaining (60\%) were downregulated after $R b$-Pten deletion (Fig. 4A). The proportions of upregulated and downregulated genes were comparable, suggesting that the analyses were consistent. Included in the top 20 upregulated genes were Il-6, several chemokine genes, and lysyl oxidase (Lox) (Fig. $4 \mathrm{~B}$, and S1A and B).

We performed Gene Set Enrichment Analysis (GSEA) between a gene set upregulated in $\operatorname{Trp} 53^{-/-} ; R b^{f / f}$ cells after AD-Cre infection as compared to AD-LacZ and a gene set featuring embryonic stem (ES) cells (Fig. S2). This analysis indicated that the stem cell-like phenotype induced in our prostate cells is associated with induction of embryonic gene expression.

Expression of the cytokine and chemokine genes detected in the studies mentioned immediately above (Il-6, Ccl5 and Cxcl5) and an Il-6 family member Lif (Leukemia inhibitory factor) were further assessed by RT-qPCR in $\operatorname{Trp}_{53}{ }^{-/-}$, Pten $^{\text {f/f }}$ cells infected with AD-LacZ or AD-Cre (Fig. 5A-D). We also examined Lox (Fig. 5E) as it had the highest level of fold induction and statistical significance among genes related to the extracellular matrix. We observed that Il-6 and Lox expression levels correlated very well with the prostasphere-forming and tumorigenic activity of our prostate epithelial cells (Fig. 2A, and 5A and E).

We assessed the molecular mechanism of Il-6 and Lox induction in Rb and/or Pten deletions. An IKK2 inhibitor, which blocks the NF- $\kappa B$ pathway, strongly antagonized Il-6 induction following the deletion of $R b$ and Rb/Pten (Fig. S3A). As expected, an E2F inhibitor (Fig. S3B) and an AKT inhibitor (Fig. S3C) significantly antagonized Il-6 induction following the deletion of $R b$ or Pten. Lox induction in $T r p 53^{-/-} ; R b^{f / f}$; Pten $^{f / f}$ prostate epithelial was antagonized by an E2F inhibitor (Fig. S3D). These findings indicate that in our prostate cancer models, $\mathrm{Rb}$ and Pten influenced $\mathrm{Il}-6$ expression through E2F and AKT respectively. Unlike Il-6, Lox induction was not sensitive to the IKK2 inhibitor (data not shown) suggesting that immediate upstream molecules of these genes are different in the context that we examined.

\section{Il-6 and Lox contribute to prostasphere formation}

We assessed the contribution of Il-6 and Lox to the malignant behavior of our prostate epithelial cells. First, to examine whether Il-6 expressed in our prostate cells is functional, we examined STAT3 activity. Deletion of $R b$ and/or Pten significantly increased the phosphorylated form of STAT3, while it did not affect activity of other signaling molecules, including ERK, SRC, and FAK (Fig. 6A). Increased phosphorylation of AKT was observed in Pten-deleted cells (Fig. 6A), consistent with the known function of Pten. Treatment of $\operatorname{Trp} 53^{-/-}$prostate epithelial cells with recombinant Il-6 (rIl-6) induced acute activation of STAT3 with no overt influence on either ERK or AKT activity (Fig. 6B). These findings support that Il-6-STAT3 pathway is intact in our prostate epithelial cells.

Importantly, treatment of $\operatorname{Trp} 53^{-/-}$prostate epithelial cells with rIl-6 significantly increased their prostasphere-forming activity (Fig. 6C), indicating the possibility that increased Il-6 production after deletion of $R b$ and/or Pten contributes to an increase in sphere-forming activity. To further examine this possibility, we successfully depleted Il-6 using the short hairpin RNA-interfering technique (Fig. S1C). Il-6 depletion 
significantly decreased basal levels of prostasphere-forming activities in $\operatorname{Trp} 53^{-/-}$ prostate epithelial cells (Fig. 6D), and moreover antagonized effects of the deletion of $R b$ and/or Pten (Fig. 6D). These findings suggest that Il-6 produced by Trp53-/prostate epithelial cells is involved in sustaining their prostasphere-forming activities. Additionally, increased Il-6 production induced by depletion of $R b$ and/or Pten contributed to increased formation of spheres. Importantly, depletion of Il-6 significantly antagonized tumorous propagation of $R b$ and Pten-deleted Trp53 ${ }^{-/-}$ prostate epithelial cells in KSN athymic mice (Fig. 6E). The effects of Il-6 depletion in vivo was much more robust than assessed in the in vitro prostasphere assay (Fig. 6D), suggesting that blocking Il-6 signaling may be more effective in an in vivo therapy.

Blockade of Il-6-STAT3 signaling by anti-Il-6R antibody treatment, although not as robust as that with Il-6 shRNA treatment, decreased prostasphere-forming activities in all genotypes of $\operatorname{Tr} 553^{-/-}$prostate epithelial cells (Fig. 7A). A similar effect was observed when cells were treated with a STAT3 inhibitor, Stattic (Fig. 7B and C).

We next focused on Lox, whose expression was as well tightly correlated with prostasphere-forming activity. Depletion of Lox in our cells was very efficient (Fig. 7D). Lox depletion also significantly antagonized prostasphere-forming activities in all cells examined (Fig. 7E).

We lastly assessed the effects of the interventions that we used in the sphere formation assay to study their impact on cell proliferation under 2D culture conditions. Addition of rIL-6 did not significantly enhanced cell proliferation within $48 \mathrm{hr}$ of observation (Fig. S4A). Depletion of Il-6 or treatment with anti-Il-6 Ab did not show remarkable effects on cell proliferation (Fig. S4B and C). Treatment with Stattic for $48 \mathrm{hr}$ however severely abrogated cell proliferation, indicating toxicity of this reagent (data not shown). Lox depletion within $48 \mathrm{hr}$ did not show significant impact on cell proliferation (data not shown), however extended observation (96 hr) revealed that this antagonized increased proliferation induced by the deletion of $R b$ and Pten (Fig. S4D). These findings indicate that the effects of Il-6 and Lox inhibition onto sphere formation and cell proliferation might be different.

\section{DISCUSSION}

To examine if genes affected by the $R B$ and PTEN status in prostate cancer cells might be mechanistically related to their malignant progression, we established an in vitro system to identify Rb and Pten-targeted genes in Trp53-deficient prostate epithelial cells. By altering genetic background to Trp53/- and using ProstaCult ${ }^{\mathrm{TM}}$ media, we easily derived $\mathrm{CK}^{+}, \mathrm{AR}^{\mathrm{LOW}}$ basal-like prostate epithelial cells from mouse prostate gland. Additional depletion of Rb and/or Pten from these cells induced higher sphere forming activity and the ability to initiate a $\mathrm{CK} 18^{+}, \mathrm{AR}^{+}, \mathrm{E}$-cadherin ${ }^{+}$luminal type tumor in athymic mice. Subsequently, we determined targets of RB and PTEN in our Trp53-null prostate epithelial cells. We identified that changes in Il-6 and Lox were positively correlated with spherogenic activity, and therefore we selected them for further analysis.

Although IL-6 is highly expressed in prostate cancer stem cells [20-22], its 
pathological significance is unclear. As has been demonstrated by us and others, IL-6 activates STAT3 in prostate cancer cells, and inhibition of STAT3 signaling abrogates IL-6 production [23-26]. Therefore, it is highly probable that $R b$ and/or Pten loss in our system enhanced a positive feed forward loop between Il-6 and STAT3. The IL-6STAT3 pathway has been implicated in the undifferentiated phenotypes or chemoresistance exerted by many types of cancers [21,27-32]. Thus we propose that IL-6 plays a role in driving malignant progression and stem cell-like activity of prostate cancers.

The limited effect of Il-6 depletion, anti-Il-6R Ab treatment and Stattic treatment on prostasphere formation (Fig. 7A, B and C) indicated that Il-6 is not solely responsible for prostasphere formation. We identified another molecule, Lox, which was upregulated by the deletion of $R b$ and/or Pten, and also highly correlated with prostasphere formation activity. LOX modulates the extracellular matrix through its enzymatic activity, which initiates crosslinking of collagen and elastin [33]. LOX also participates in oxygenation of lysine residues in a number of proteins as well [34]. LOX has been proposed to promote the escape from cellular senescence, tumor initiation and progression, and also to enhance invasive and metastatic phenotypes in breast and colorectal cancers [35,36]. However, several reports indicate that LOX could be involved in the reversion of Ras-transformation. Although there are lively debates on the exact role of this molecule in different cancers [37], our results indicate LOX may have a role in controlling stem cell-like activities in prostate cancers.

In conclusion, our attempt to determine the signature of $\mathrm{Rb}$ and/or Pten loss-offunction in $\operatorname{Tr} 553^{-/-}$prostate epithelial cells resulted in identification of two molecules that possibly contribute to stem cell-like activity in prostate cancer cells. Further investigation of signaling innervated by these two molecules might provide new insight to the mechanism of prostate cancer progression, as $R b$ and Pten are frequently inactivated during its progression [38,39]. An in vivo model of prostate cancer with $R b$ and Trp53 mutations arising from the stem/progenitor-enriched proximal region in the prostatic ducts [40] might further support the results found in our in vitro model. Although our in vitro models required several steps of manipulations before establishment of cell lines for analysis, it has enabled us to identify unexpected molecules that are involved in malignant behaviors of prostate cancer cells. Encouraged by such achievements, we are currently extending the development of our in vitro models to sarcomas, breast and lung cancers.

\section{ACKNOWLEDGMENTS}

We thank Dr. A. Berns, Dr. A. Suzuki and Riken BBRC for providing materials, and Drs. Asano and Kamimura for assistance in animal experiments. This work was supported by Funding Program for Next Generation World-Leading Researchers (NEXT), Grant-in-Aid for Scientific Research (MEXT), Astellas Foundation for Research on Metabolic Disorders, Takeda Science Foundation, Naito Foundation, Daiichi-Sankyo Foundation for Life Science, NOVARTIS Foundation (Japan) for Promotion of Science and Hokkoku Foundation for Cancer Research. MS thank PhD Channel Program provided by Egyptian Ministry of Higher Education for support.

\section{REFERENCES}


1. Wang L, Xiong H, Wu F, Zhang Y, Wang J, Zhao L, Guo X, Chang LJ, Zhang Y, You MJ, Koochekpour S, Saleem M, Huang H, Lu J, Deng Y. Hexokinase 2-mediated Warburg effect is required for PTEN- and Trp53deficiency-driven prostate cancer growth. Cell Rep 2014;8(5):1461-1474.

2. Bookstein R, Rio P, Madreperla SA, Hong F, Allred C, Grizzle WE, Lee WH. Promoter deletion and loss of retinoblastoma gene expression in human prostate carcinoma. Proc Natl Acad Sci USA 1990;87:7762-7766.

3. Tricoli JV, Gumerlock PH, Yao JL, Chi SG, D'Souza SA, Nestok BR, deVere White RW. Alterations of the retinoblastoma gene in human prostate adenocarcinoma. Genes Chromosomes Cancer 1996;15:108-114.

4. Schrecengost R, Knudsen KE. Molecular Pathogenesis and Progression of Prostate Cancer. Seminars in Oncology 2013;40(3):244-258.

5. Downing SR, Russell PJ, Jackson P. Alterations of Trp53 are common in early stage prostate cancer. Can J Urol 2003;10:1924-1933.

6. Zhou Z, Flesken-Nikitin A, Corney DC, Wang W, Goodrich DW, RoyBurman P, Nikitin AY. Synergy of Trp53 and Rb deficiency in a conditional mouse model for metastatic prostate cancer. Cancer Res 2006;66(16): 78897898.

7. Sircar K, Yoshimoto M, Monzon FA, Koumakpayi IH, Katz RL Khanna A, Alvarez K, Chen G, Damel AD, Aprikian AG, Saad F, Bismar TA, Squire JA. PTEN genomic deletion is associated with p-Akt and AR signalling in poorer outcome, hormone refractory prostate cancer. $\mathrm{J}$ Pathol 2009;218:505-513.

8. Chen Z, Trotman LC, Shaffer D, Lin HK, Dotan ZA, Niki M, Koutcher JA, Scher HI, Ludwig T, Gerald W, Cordon-Cardo C, Pandolfi PP. Crucial role of Trp53-dependent cellular senescence in suppression of Pten-deficient tumorigenesis. Nature 2005;436(7051):725-730.

9. Martin P, Liu YN, Pierce R, Abou-Kheir W, Casey O, Seng V, Camacho D, Simpson RM, Kelly K. Prostate epithelial Pten/TTRP53 loss leads to transformation of multipotential progenitors and epithelial to mesenchymal transition. Am J Pathol 2011;179:422-435.

10. Haffner MC, Mosbruger T, Esopi DM, Fedor H, Heaphy CM, Walker DA, Adejola N, Gürel M, Hicks J, Meeker AK, Halushka MK, Simons JW, Isaacs WB, De Marzo AM, Nelson WG, Yegnasubramanian S. Tracking the clonal origin of lethal prostate cancer. J Clin Invest 2013;123(11):4918-4922.

11. Goldstein AS, Witte ON. Does the microenvironment influence the cell types of origin for prostate cancer? Genes Dev. 2013;27:1539-1544.

12. Stoyanova T, Cooper AR, Drake JM, Liu X., Armstrong AJ, Pienta KJ, Zhang H, Kohn, DB, Huang J, Witte ON, Goldstein, A.S. Prostate cancer originating in basal cells progresses to adenocarcinoma propagated by luminal-like cells. Proc. Natl. Acad. Sci. USA 2013;110:20111-20116. 
13. Taylor RA, Toivanen R, Frydenberg M, Pedersen J, Harewood L, Collins AT, Maitland NJ, Risbridger GP, Australian Prostate Cancer Bioresource. Human epithelial basal cells are cells of origin of prostate cancer, independent of CD133 status. Stem Cells 2012;30:1087-1096.

14. Tsukada T, Tomooka Y, Takai S, Ueda Y, Nishikawa S, Yagi T, Tokunaga T, Takeda N, Suda Y, Abe S. Enhanced proliferative potential in culture of cells from Trp53-deficient mice. Oncogene 1993;8:3313-3322.

15. Marino S, Vooijs M, van Der Gulden H, Jonkers J, Berns A. Induction of medulloblastomas in Trp53-null mutant mice by somatic inactivation of $\mathrm{Rb}$ in the external granular layer cells of the cerebellum. Genes Dev 2000;14:9941004.

16. Suzuki A, Yamaguchi MT, Ohteki T, Sasaki T, Kaisho T, Kimura Y, Yoshida R, Wakeham A, Higuchi T, Fukumoto M, Tsubata T, Ohashi PS, Koyasu S, Penninger JM, Nakano T, Mak TW. T cell-specific loss of Pten leads to defects in central and peripheral tolerance. Immunity 2001;14:523534.

17. Kitajima S, Miki T, Takegami Y, Kido Y, Noda M, Hara E, Shamma A, Takahashi C. Reversion-inducing cysteine-rich protein with Kazal motifs interferes with epidermal growth factor receptor signaling. Oncogene 2011;30(6):737-750.

18. Kitajima S, Kohno S, Kondoh A, Sasaki N, Nishimoto Y, Li F, Mohammed MS, Muranaka H, Nagatani N, Suzuki M, Kido Y, Takahashi C. Undifferentiated State Induced by Rb-Trp53 Double Inactivation in Mouse Thyroid Neuroendocrine Cells and Embryonic Fibroblasts. Stem Cells 2015;33(5):1657-1669.

19. Lukacs RU, Goldstein AS, Lawson DA, Cheng D, Witte ON. Isolation, cultivation and characterization of adult murine prostate stem cells. Nat Protoc 2010;5(4):702-713.

20. Bao B, Ahmad A, Kong D, Ali S, Azmi AS, Li Y, Banerjee S, Padhye S, Sarkar FH. Hypoxia induced aggressiveness of prostate cancer cells is linked with deregulated expression of VEGF, IL-6 and miRNAs that are attenuated by CDF. PLoS One 2012;7(8):e43726.

21. Kroon P, Berry PA, Stower MJ, Rodrigues G, Mann VM, Simms M, Bhasin D, Chettiar S, Li C, Li PK, Maitland NJ, Collins AT. JAK-STAT blockade inhibits tumor initiation and clonogenic recovery of prostate cancer stem-like cells. Cancer Res 2013;73(16):5288-5298.

22. Qu Y, Oyan AM, Liu R, Hua Y, Zhang J, Hovland R, Popa M, Liu X, Brokstad KA, Simon R, Molven A, Lin B, Zhang WD, McCormack E, Kalland $\mathrm{KH}, \mathrm{Ke}$ XS. Generation of prostate tumor-initiating cells is associated with elevation of reactive oxygen species and IL-6/STAT3 signaling. Cancer Res 2013;73(23):7090-7100. 
23. Lou W, Ni Z, Dyer K, Tweardy DJ, Gao AC. Interleukin-6 induces prostate cancer cell growth accompanied by activation of STAT3 signaling pathway. Prostate 2000; 42:239-242.

24. Heinrich P, Behmann I, Muller-Newen G, Schaper F, Graeve L. Interleukin-6-type cytokine signalling though the gp130/Jak/STAT pathway. Biochem J 1998;334:297-314.

25. Wallner L, Dai J, Escara-Wilke J, Zhang J, Yao Z, Lu Y, Trikha M, Nemeth JA, Zaki MH, Keller ET. Inhibition of interleukin-6 with CNTO328, an anti-interleukin-6 monoclonal antibody, inhibits conversion of androgendependent prostate cancer to an androgen-independent phenotype in orchiectomized mice. Cancer. Res 2006;66(6):3087-95.

26. Barton BE, Murphy TF, Shu P, Huang HF, Meyenhofer M, Barton A. Novel single-stranded oligonucleotides that inhibit signal transducer and activator of transcription 3 induce apoptosis in vitro and in vivo in prostate cancer cell lines. Mol Cancer Ther 2004;3(10):1183-1191.

27. Marotta LL, Almendro V, Marusyk A, Shipitsin M, Schemme J, Walker SR, Bloushtain-Qimron N, Kim JJ, Choudhury SA, Maruyama R, Wu Z, Gönen M, Mulvey LA, Bessarabova MO, Huh SJ, Silver SJ, Kim SY, Park SY, Lee HE, Anderson KS, Richardson AL, Nikolskaya T, Nikolsky Y, Liu XS, Root DE, Hahn WC, Frank DA, Polyak K. The JAK2/STAT3 signaling pathway is required for growth of $\mathrm{CD} 44^{+} \mathrm{CD} 24^{-}$stem cell-like breast cancer cells in human tumors. J Clin Invest 2011;121(7):2723-2735.

28. Sansone P, Storci G, Tavolari S, Guarnieri T, Giovannini C, Taffurelli M, Ceccarelli C, Santini D, Paterini P, Marcu KB, Chieco P, Bonafè M. IL-6 triggers malignant features in mammospheres from human ductal breast carcinoma and normal mammary gland. J Clin Invest 2007;117(12):3988-4002.

29. Wang H, Lathia JD, Wu Q, Wang J, Li Z, Heddleston JM, Eyler CE, Elderbroom J, Gallagher J, Schuschu J, MacSwords J, Cao Y, McLendon RE, Wang XF, Hjelmeland AB, Rich JN. Targeting interleukin 6 signaling suppresses glioma stem cell survival and tumor growth. Stem Cells 2009;27(10):2393-2404.

30. Liu Y, Li PK, Li C, Lin J. Inhibition of STAT3 signaling blocks the anti-apoptotic activity of IL-6 in human liver cancer cells. J Biol Chem 2010;285(35):27429-27439.

31. Alas S, Bonavida B. Inhibition of constitutive STAT3 activity sensitizes resistant non-Hodgkin's lymphoma and multiple myeloma to chemotherapeutic drug-mediated apoptosis. Clin Cancer Res 2003;9(1):316326.

32. Ara T, Nakata R, Sheard MA, Shimada H, Buettner R, Groshen SG, Ji L, Yu H, Jove R, Seeger RC, DeClerck YA. Critical role of STAT3 in IL-6mediated drug resistance in human neuroblastoma. Cancer Res 2013;73(13):3852-64. 
33. Csiszar K. Lysyl oxidases: a novel multifunctional amine oxidase family. Prog Nucleic Acid Res Mol Biol 2001;70:1-32.

34. Lucero H, Kagan HM. Lysyl oxidase: an oxidative enzyme and effector of cell function. Cell Mol Life Sci 2006;63:2304-2316.

35. Barker HE, Chang J, Cox TR, Lang G, Bird D, Nicolau M, Evans HR, Gartland A, Erler JT. LOXL2-mediated matrix remodeling in metastasis and mammary gland involution. Cancer Res 2011;71:1561-1572.

36. Baker AM, Cox TR, Bird D, Lang G, Murray GI, Sun XF, Southall SM, Wilson JR, Erler JT. The role of lysyl oxidase in SRC-dependent proliferation and metastasis of colorectal cancer. J Natl Cancer Inst 2011;103:407-424.

37. El-Haibi CP, Bell GW, Zhang J, Collmann AY, Wood D, Scherber CM, Csizmadia E, Mariani O, Zhu C, Campagne A, Toner M, Bhatia SN, Irimia D, Vincent-Salomon A, Karnoub AE. Critical role for lysyl oxidase in mesenchymal stem cell-driven breast cancer malignancy. Proc Natl Acad Sci U S A 2012;109(43):17460-17465.

38. Sharma A, Yeow WS, Ertel A, Coleman I, Clegg N, Thangavel C, Morrissey C, Zhang X, Comstock CE, Witkiewicz AK, Gomella L, Knudsen ES, Nelson PS, Knudsen KE. The retinoblastoma tumor suppressor controls androgen signaling and human prostate cancer progression. J Clin Invest 2010;120(12):4478-4492.

39. Mulholland DJ, Kobayashi N, Ruscetti M, Zhi A, Tran LM, Huang J, Gleave $\mathrm{M}, \mathrm{Wu} \mathrm{H}$. Pten loss and RAS/MAPK activation cooperate to promote EMT and metastasis initiated from prostate cancer stem/progenitor cells. Cancer Res 2012;72(7):1878-1889.

40. Zhou Z, Flesken-Nikitin A, Nikitin AY. Prostate cancer associated with Trp53 and Rb deficiency arises from the stem/progenitor cell-enriched proximal region of prostatic ducts. Cancer Res 2007;67:5683-5690.

\section{FIGURE LEGENDS}


A

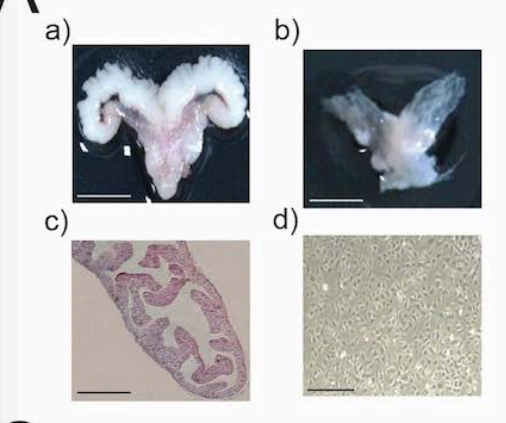

C

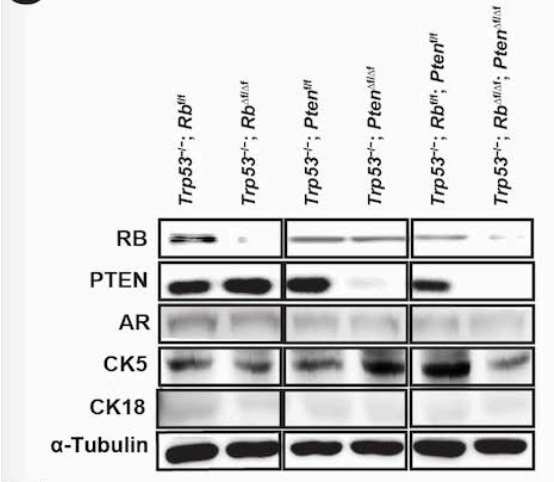

$E$
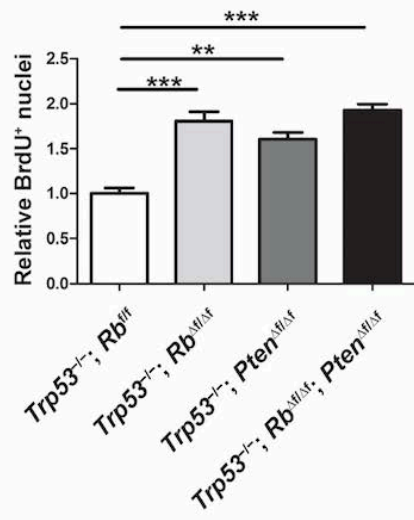

B

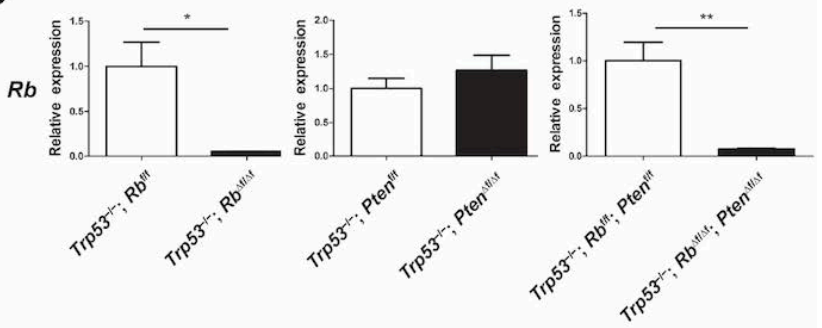

$\mathrm{D}$

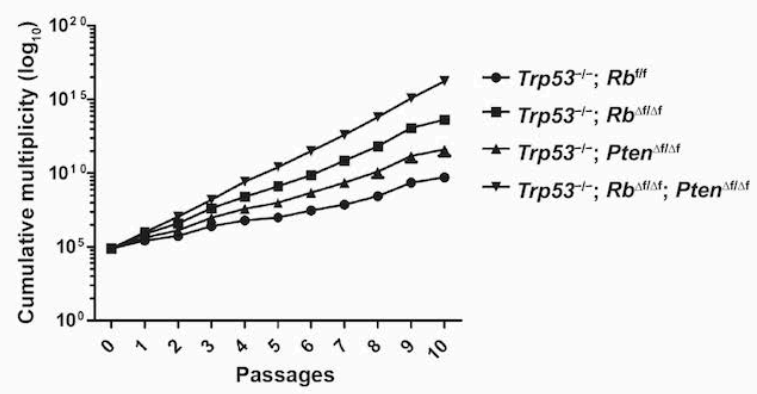

$\mathrm{F}$
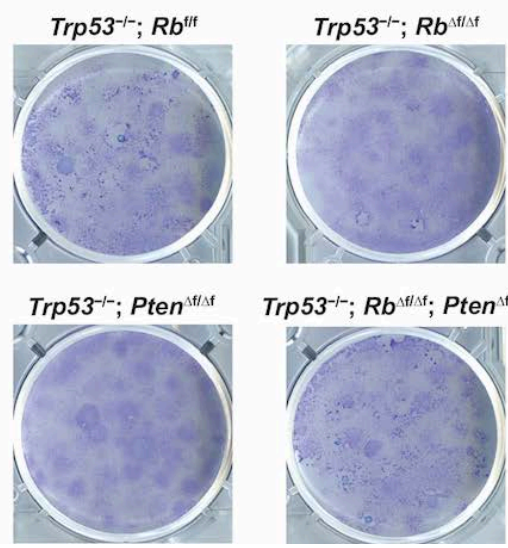

$\operatorname{Trp53^{-1-}} ; R^{\Delta f / \Delta f} ; P t e n^{\Delta f / \Delta f}$

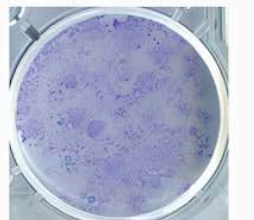

Figure 1.

(A): a) Image shows the entire murine urogenital sinus including seminal vesicles, prostate, urethra and urinary bladder. Scale bar: $5 \mathrm{~mm}$. b) Image shows whole murine prostate including anterior, dorsolateral and ventral lobes. Scale bar: $5 \mathrm{~mm}$. c) An H\&E-stained section of the anterior lobe of isolated prostate. Scale bar: $300 \mu \mathrm{m} . \mathrm{d}$ ) Prostate cells cultivated with serum-free ProstaCult ${ }^{\mathrm{TM}}$ media supplemented with recombinant human (rh) bFGF and rh EGF. Scale bar: $500 \mu \mathrm{m}$. (B): RT-qPCR of $R b$ in cells derived from prostate of the indicated genotypes of mice. Columns: relative levels plus standard deviation (S.D.). $(\mathrm{N}=3)$. ${ }^{*} P<0.05$ and $* * P<0.01$ (Student's ttest). $R b^{f / f}$; Pten ${ }^{f / f}$ : cells infected with AD-LacZ and $R b^{\Delta f / \Delta f}$; Pten ${ }^{\Delta f / \Delta f}$ : cells infected with $\mathrm{AD}$-Cre (C): Immunoblotting (IB) of the indicated proteins in the indicated genotype of primary prostate cells. (D): Assessment of cell proliferation of the indicated genotype of primary prostate cells. (E): Quantification of BrdU incorporation by the indicated genotype of cells. Columns: relative frequency plus S.D. $\left(\mathrm{N}=3\right.$ ). ${ }^{* * P}<0.01$ and $* * * P<0.001$ (one-way ANOVA followed by post-hoc Tukey's test). The statistical differences between columns not indicated with asterisks 
are not statistically significant unless otherwise indicated. (F) $6 \times 10^{3}$ prostate epithelial cells of the indicated genotypes were plated in a collagen-coated 6-well plate. After 14 day incubation, resultant colonies were visualized.

A
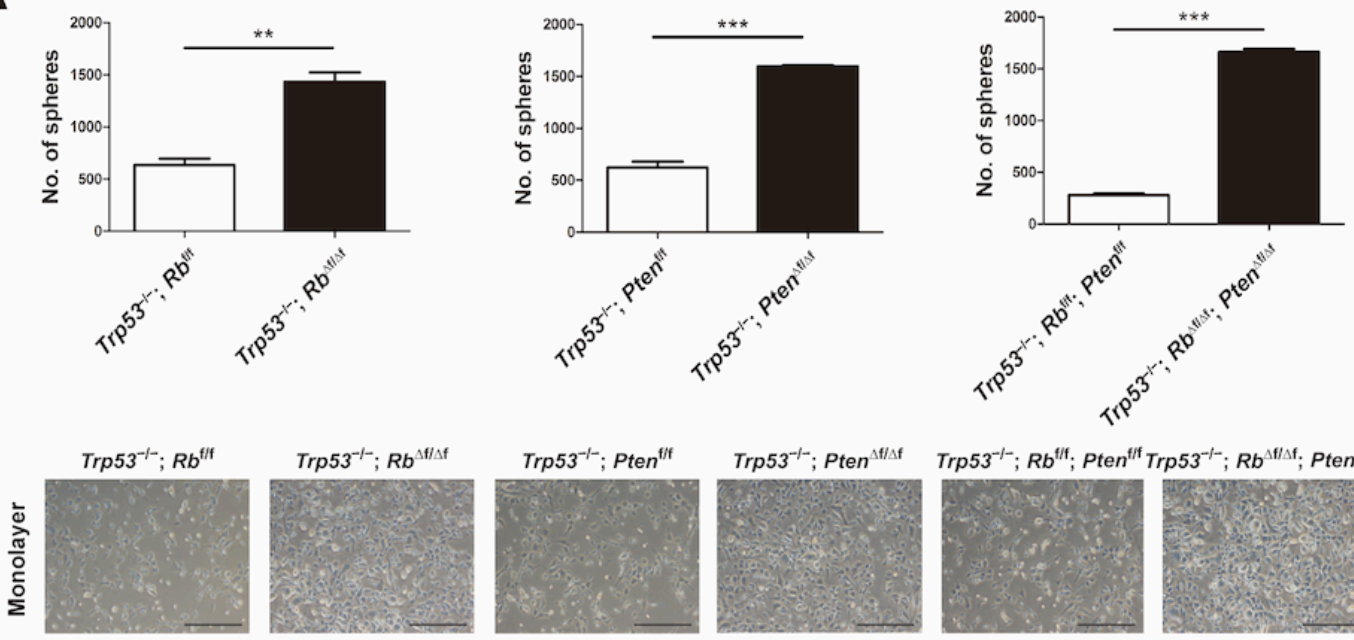

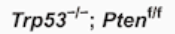

$\operatorname{Trp}^{\mathrm{s} 3^{-1-}} ; \operatorname{Pten}^{\Delta / / \Delta f}$

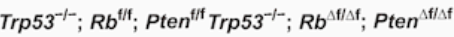

के
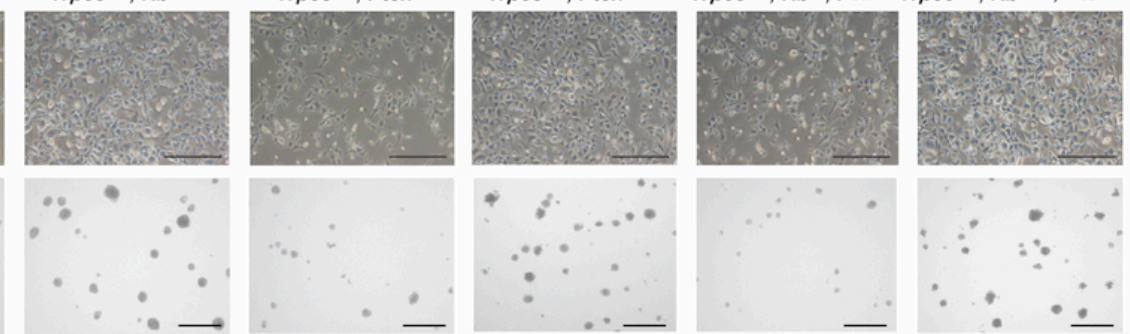

B
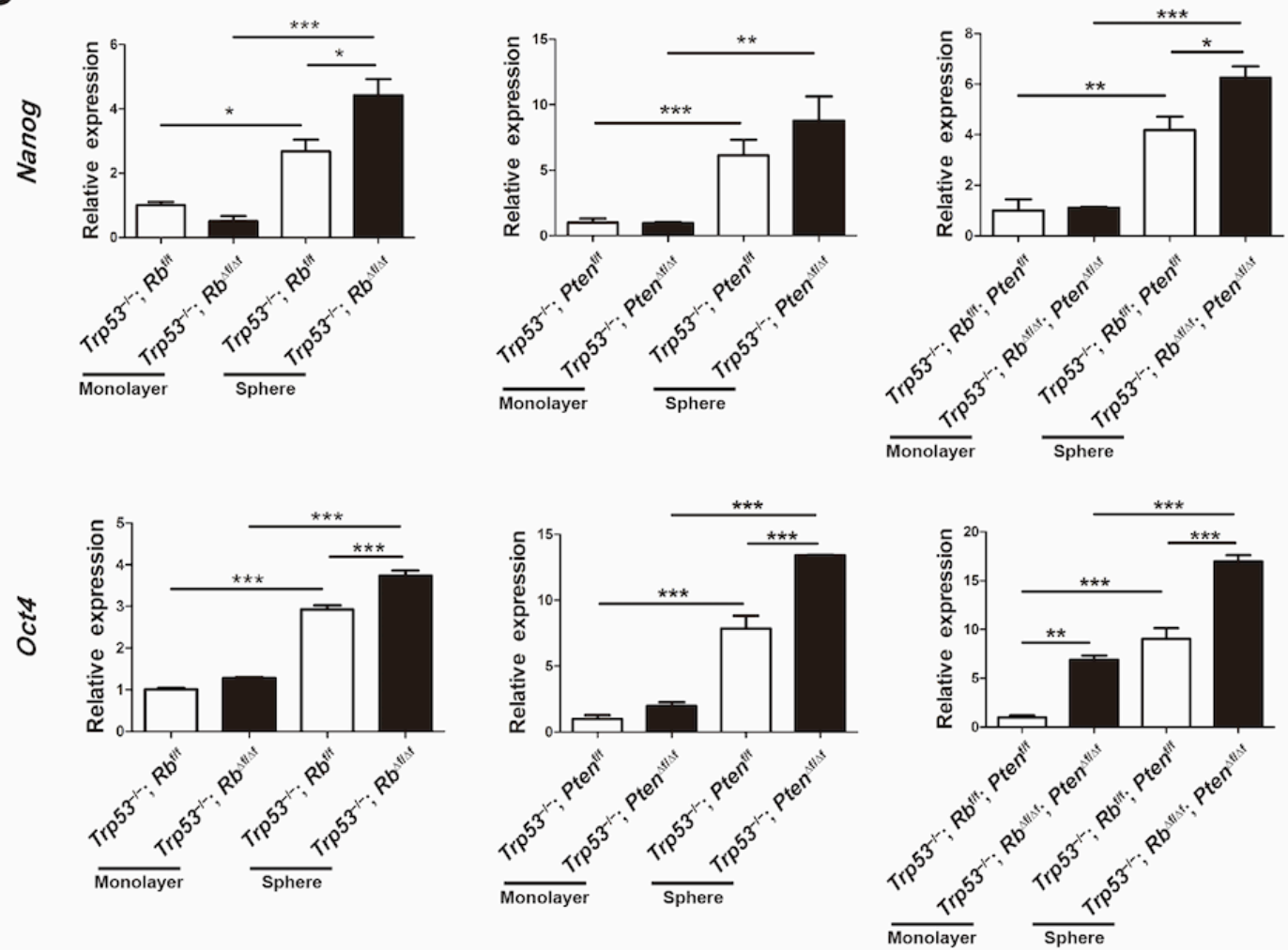

Figure 2.

(A): Sphere assay of the indicated genotype of primary prostate cells. $5 \times 10^{4}$ cells were seeded on day 0 and observed on day 14 . Average number of spheres larger than 
$3 \mathrm{~mm}^{2}$ was calculated. Columns: relative frequency plus S.D. $(\mathrm{N}=3) . * * P<0.01$ and $* * * P<0.001$ (one-way ANOVA followed by post-hoc Tukey's test). Monolayer (upper) and sphere (lower) culture of indicated genotype of prostate epithelial cells. Scale bar: $500 \mu \mathrm{m}$. (B): RT-qPCR of Nanog and Oct-4 in the indicated genotypes of prostate epithelial cells cultured under the indicated conditions. Columns: relative frequency plus S.D. $\left(\mathrm{N}=3\right.$ ). ${ }^{*} P<0.05, * * P<0.01$ and $* * * P<0.001$ (one-way ANOVA followed by post-hoc Tukey's test).

A
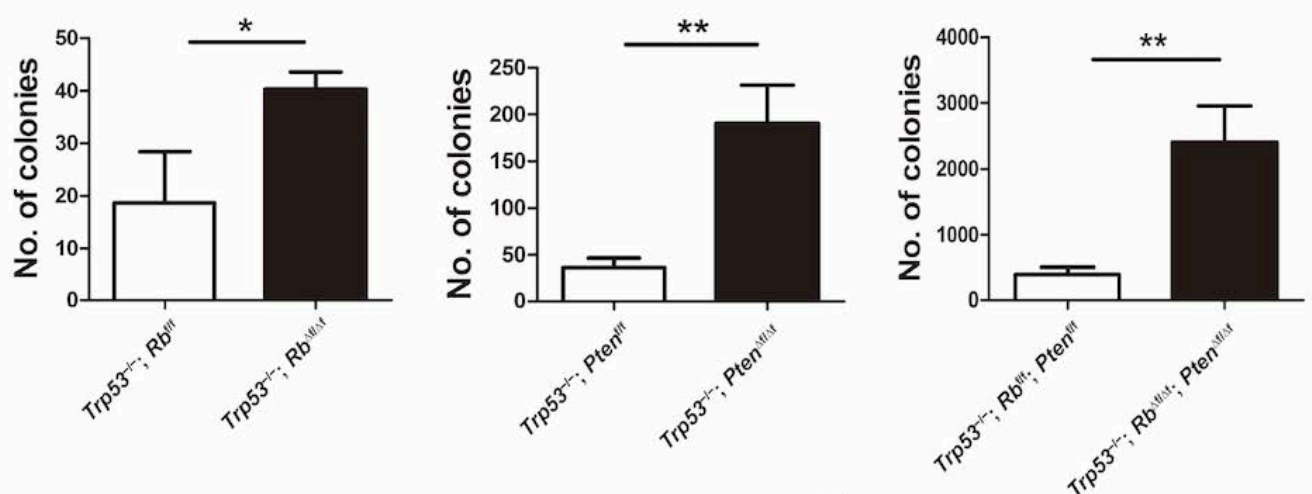

B
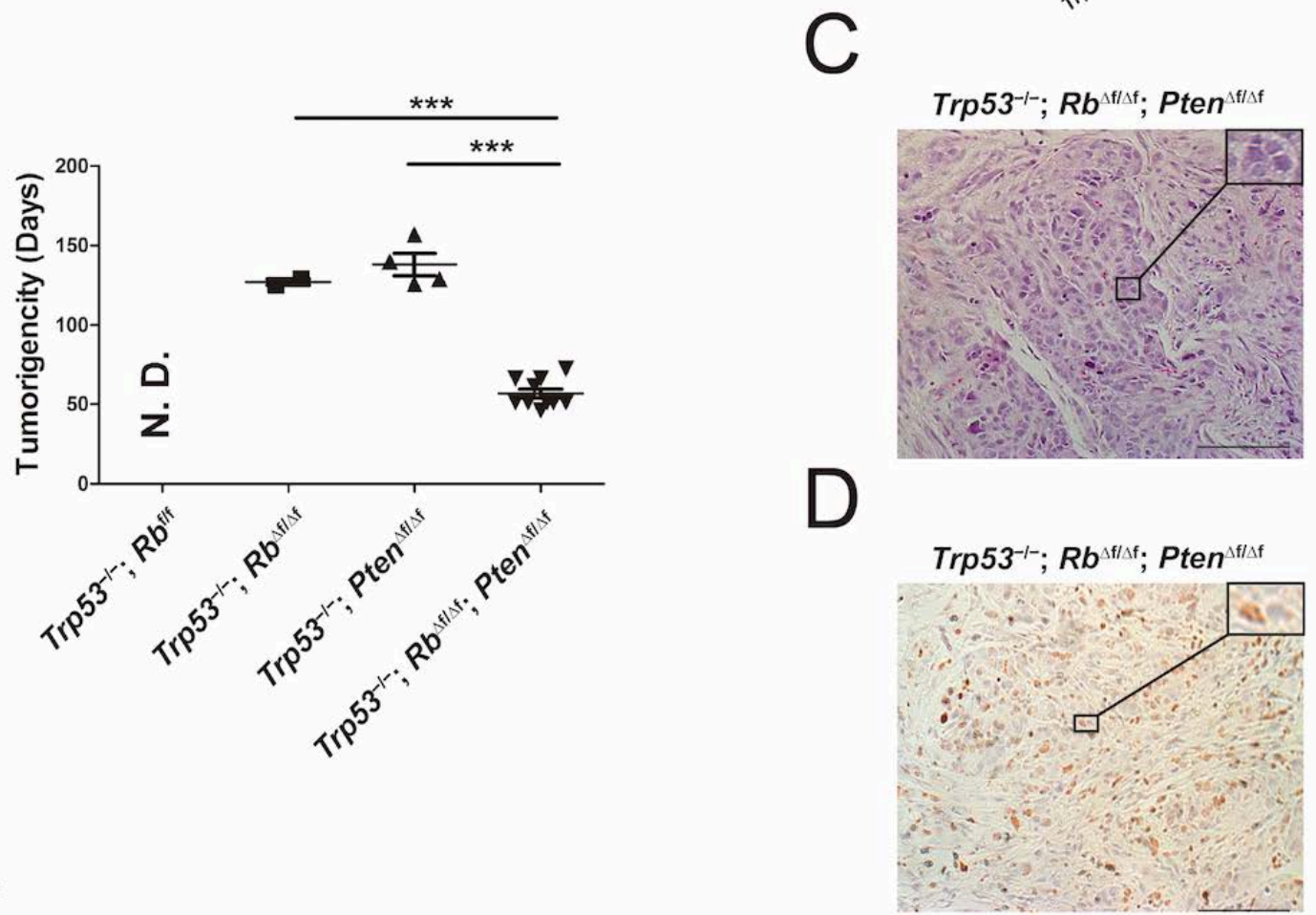

AR

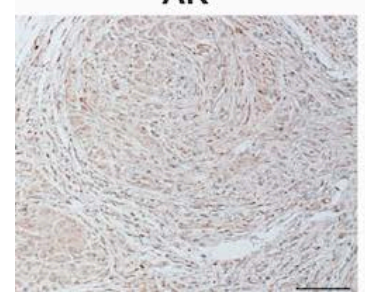

CK18

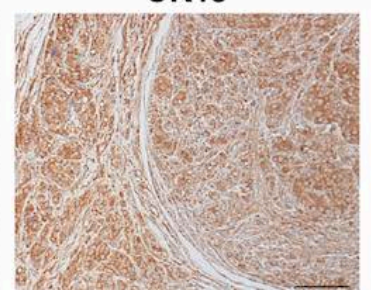

E-cad

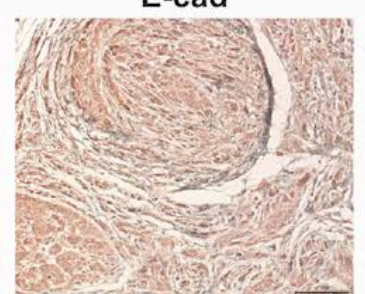

CK5

Figure 3.

(A): Soft agar assay of the indicated genotype of prostate epithelial cells. 1 x $10^{5}$ cells 
were incubated for 4 weeks. Average number of colonies larger than $2 \mathrm{~mm}^{2}$ was calculated. Columns: relative frequency plus S.D. $(\mathrm{N}=3)$. ${ }^{*} P<0.05$ and $* * P<0.01$ (Student's $t$-test). (B): Tumor developed in KSN athymic mice transplanted with the indicated genotypes of prostate epithelial cells. $3 \times 10^{6}$ cells were subcutaneously inoculated into mice. The day when tumor became detectable was recorded. Scattered plot: frequency plus S.D. $(\mathrm{N}=10) .{ }^{* * * P}<0.001$ (one-way ANOVA followed by posthoc Tukey's test). N.D.: no data. (C): H\&E staining of tumors derived from indicated genotype of prostate epithelial cells. $3 \times 10^{6}$ cells were subcutaneously inoculated into KSN athymic mice. Tumor was isolated and observed after two months. Scale bar: $200 \mu \mathrm{M}$. (D): Immuno-staining by antibody to Ki67 in the same specimen analyzed in (C). (E) Immuno-staining by antibody to the indicated proteins in the same specimen analyzed in (C). 
A

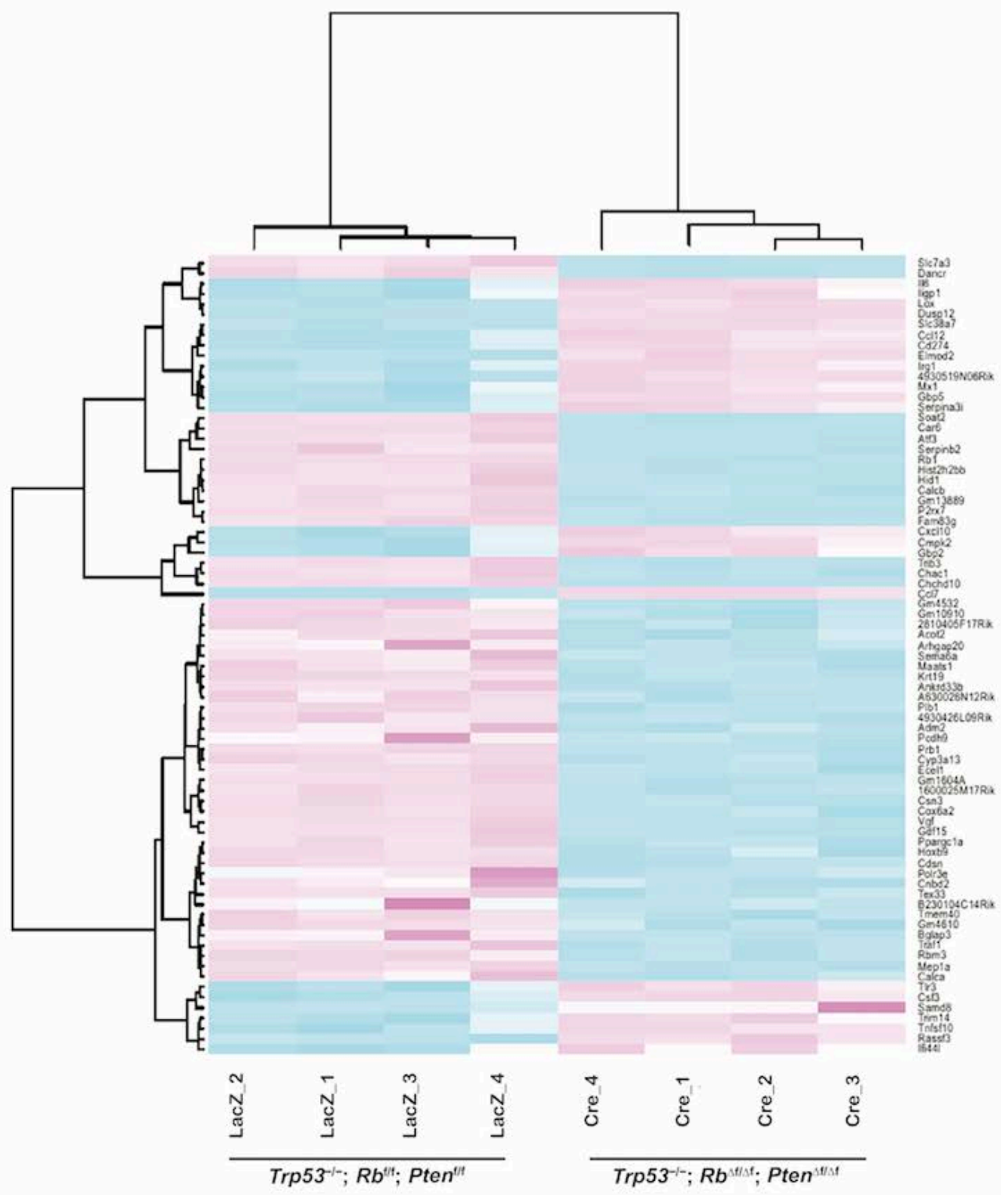

B

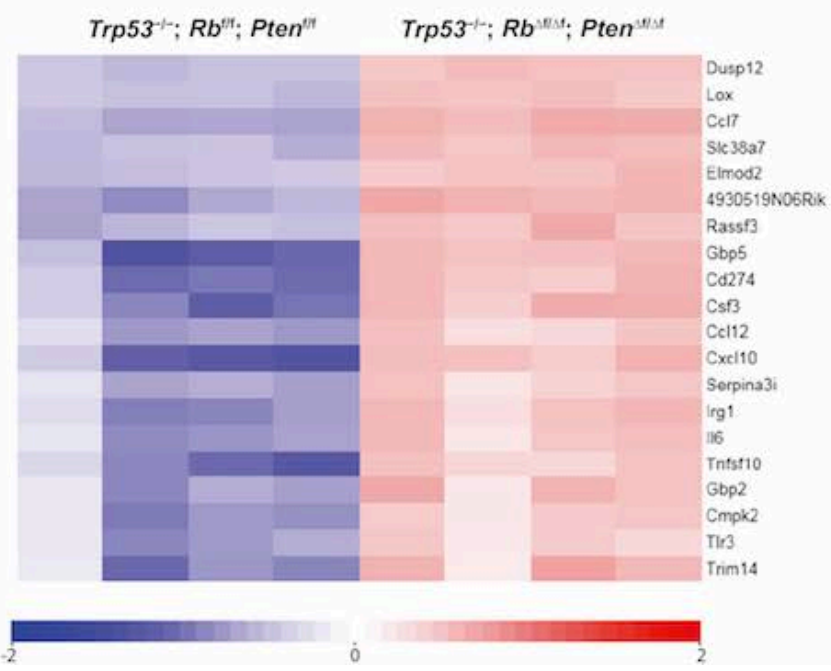




\section{Figure 4.}

(A): 26,573 entities with flags of 'detected' were extracted from 55,821 entities in microarray (Agilent \#028005) using Gene Spring 13.0-GX-PA system. From these, 118 entities with $>2$ fold change and corrected $p$ value $<0.05$ on moderated $t$-test between Cre-recombinase infected $T r p 53^{-/} ; R b^{f / f}$; Pten $^{f / f}$ prostate epithelial cells $(\mathrm{N}=$ 4) and $A D-L a c Z$ infected (control) $(\mathrm{N}=4)$ were identified. After identification of overlapped gene symbols, a data covering 77 genes was obtained. Then, using R 3.1.0, Euclidean distances in symbols and samples were individually connected on Ward methods. The result of an unsupervised clustering is indicated as a heat map. (B): Heat map for top 20 of genes (fold change) upregulated by simultaneous deletion of $\mathrm{Rb}$ and Pten in Trp53 ${ }^{-/-}$primary prostate cells compared to control $(\mathrm{N}=4)$. Red indicates upregulation while blue indicates downregulation. 
A
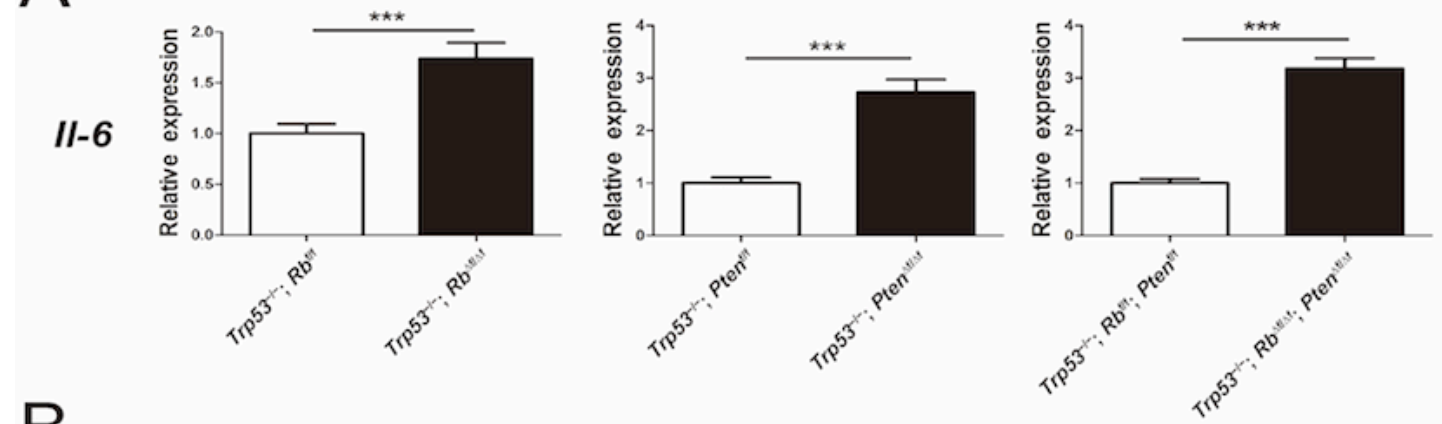

B
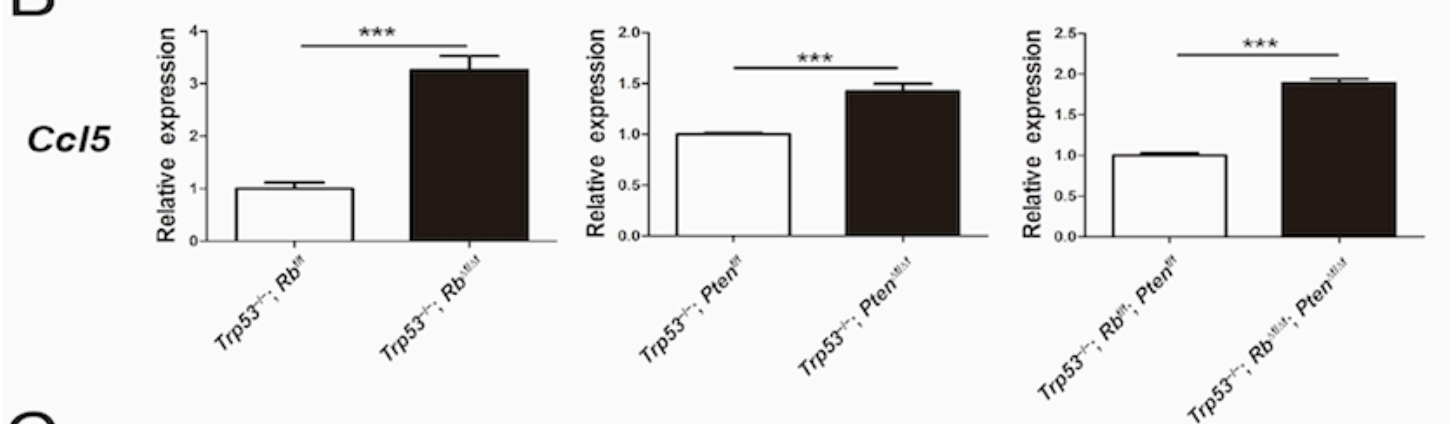

C
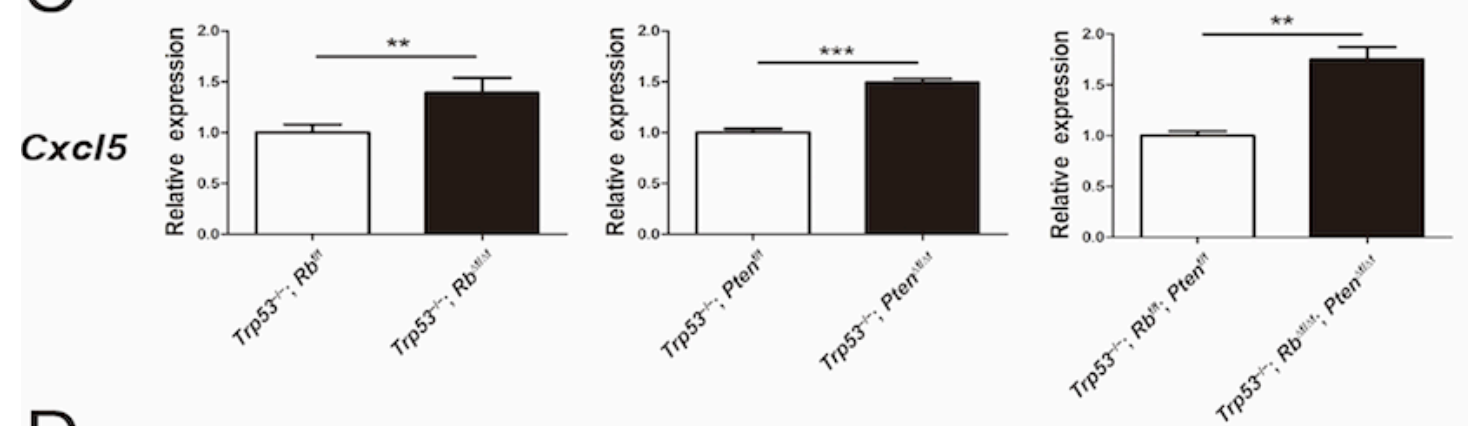

D
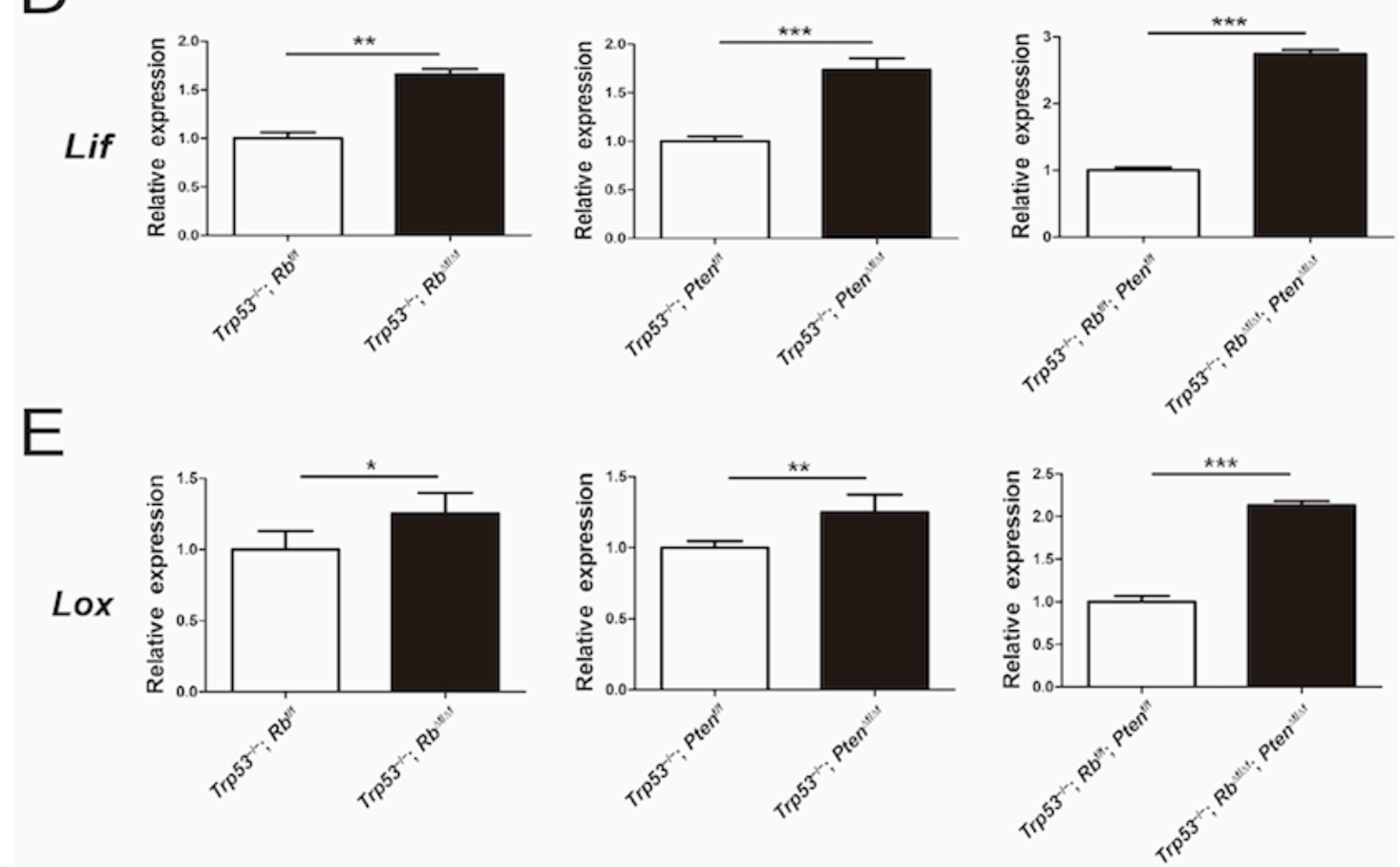

Figure 5. 
RT-qPCR of Il-6 (A), Ccl5 (B), Cxcl5 (C), Lif (D) and Lox (E) in the indicated genotypes of prostate epithelial cells. Columns: relative frequency plus S.D. $(\mathrm{N}=3)$. ${ }^{*} P<0.05,{ }^{* *} P<0.01$ and ${ }^{* * *} P<0.001$ (Student's $t$-test).

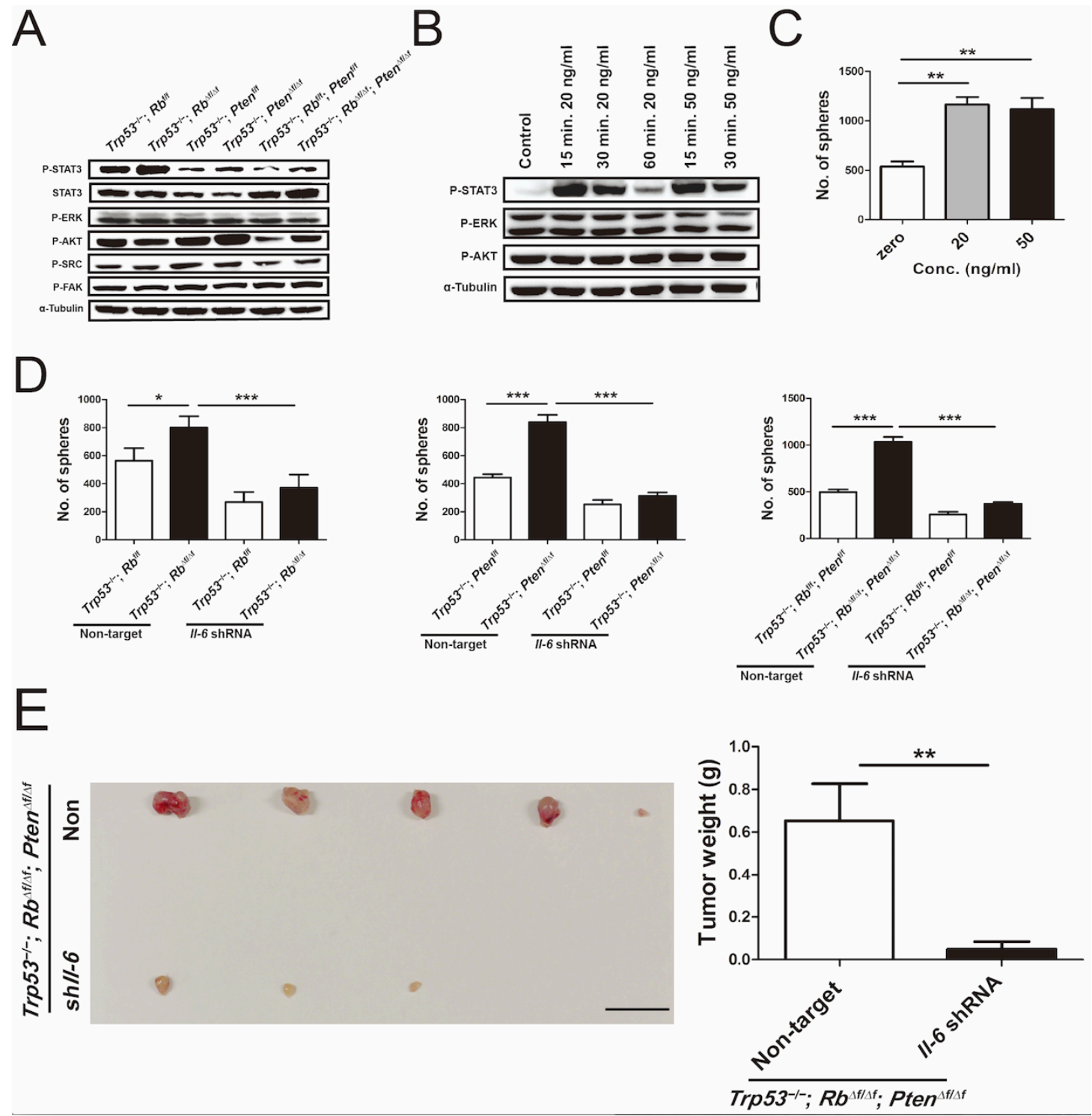

Figure 6.

(A): IB of the indicated proteins in the indicated genotype of primary prostate cells. (B): IB of the indicated proteins in $\operatorname{Trp} 53^{-/-} ; R b^{f / f}$ cells treated with $20 \mathrm{ng} / \mathrm{ml}$ or 50 ng/ml rIl-6 for the indicated time period. (C): Sphere assay of $\operatorname{Trp53^{-/-}} ; R b^{f / f}$ cells treated with 20 or $50 \mathrm{ng} / \mathrm{ml} \mathrm{rIl-6.} 5 \times 10^{4}$ cells were seeded on day 0 and observed on day 14. Columns: relative frequency plus S.D. $(\mathrm{N}=3) .{ }^{* * P}<0.01$ (Student's $t$-test). (D): Sphere of the indicated genotype of prostate epithelial cells transduced with the indicated shRNA. $5 \times 10^{4}$ cells were seeded on day 0 and observed on day 14 . Columns: relative frequency plus S.D. $(\mathrm{N}=3)$. ${ }^{*} P<0.05$ and $* * * P<0.001$ (one-way ANOVA followed by post-hoc Tukey's test). (E): Tumors developed in KSN athymic mice inoculated with indicated genotype of prostate epithelial cells transduced with the indicated shRNA. $3 \times 10^{6}$ cells were injected subcutaneously, and tumors were observed and weighed after 2 months. Columns: frequency plus S.D. $(\mathrm{N}=5)$. ${ }^{* * P}<$ 0.01 (Student's $t$-test). Scale bar: $10 \mathrm{~mm}$. 
A


Figure 7.

(A): Sphere assay of the indicated genotype of prostate epithelial cells treated with 0.4 $\mu \mathrm{g} / \mathrm{ml}$ anti-Il-6R antibody. $5 \times 10^{4}$ cells were seeded on day 0 and observed on day 14 . Columns: relative frequency plus S.D. $(\mathrm{N}=3)$. ${ }^{*} P<0.05, * * P<0.01$ and $* * * P<$ 0.001 (one-way ANOVA followed by post-hoc Tukey's test). (B): RT-qPCR of Il-6 in the indicated genotype of primary prostate cells treated with $5 \mu \mathrm{M}$ stattic for $1 \mathrm{hr}$. Dimethyl sulfoxide (DMSO): a vehicle. Columns: relative frequency plus S.D. $(\mathrm{N}=$ 3). $* P<0.05$ and $* * * P<0.001$ (one-way ANOVA followed by post-hoc Tukey's test). (C): Spheres of the indicated genotype of primary prostate cells treated with $5 \mu \mathrm{M}$ stattic. $5 \times 10^{4}$ cells were seeded on day 0 and observed on day 14 . Columns: relative 
frequency plus S.D. $(\mathrm{N}=3)$. ${ }^{*} P<0.05, * * P<0.01$ and $* * * P<0.001$ (one-way ANOVA followed by post-hoc Tukey's test). (D): RT-qPCR of Lox in Trp53 $3^{-/-} R^{f / f}$; Pten $^{f / f}$ in primary prostate cells transduced with the indicated shRNA. Columns: relative frequency plus S.D. $(\mathrm{N}=3) .{ }^{* * * P}<0.001$ (Student's t-test). (E): Spheres of the indicated genotype of primary prostate cells transduced with the indicated shRNA. $5 \times 10^{4}$ cells were seeded on day 0 and observed on day 14. Columns: relative frequency plus S.D. $(\mathrm{N}=3) .{ }^{* * P}<0.01$ (one-way ANOVA followed by post-hoc Tukey's test).

\section{Table 1.}

Gene ontology analysis of $\operatorname{Tr} 553^{-/-} ; R b^{f / f}$ prostate epithelial cells

22177 entities with flags of 'detected' were extracted from 39485 entities in microarray (Agilent \#026655) using Gene Spring 12.6.1-GX-PA system. From these, 231 entities with $>2$ fold change and corrected $p$ value $<0.05$ on moderated $t$-test between Cre-recombinase infected $\operatorname{Tr} 553^{---} ; R b^{f / f}$ prostate epithelial cells $(\mathrm{N}=3)$ and AD-LacZ infected (control) $(\mathrm{N}=3)$ were identified. The gene set was finally assessed by GO analysis on DAVID and pathway analysis on Single Enrichment Analysis (SEA).

\section{Table 2.}

Gene ontology analysis of $\operatorname{Tr} 53^{-/-} ; R b^{f / f}$; ten $^{f / f}$ prostate epithelial cells

26,573 entities with flags of 'detected' were extracted from 55,821 entities in microarray (Agilent \#028005) using Gene Spring 13.0-GX-PA system. From these, 118 entities with $>2$ fold change and corrected $p$ value $<0.05$ on moderated $t$-test between Cre-recombinase infected $\operatorname{Trp}_{53}{ }^{-/} ; \mathrm{Rb}^{\mathrm{fff}} ; \mathrm{Pten}^{\mathrm{fff}}$ prostate epithelial cells ( $\mathrm{N}=$ 4) and $A D-L a c Z$ infected (control) $(\mathrm{N}=4)$ were identified. After identification of overlapped gene symbols, a data covering 77 genes was obtained. The gene set was finally assessed by GO analysis on DAVID and pathway analysis on Single Enrichment Analysis (SEA). 


\section{GO (Molecular function)}

$\begin{array}{llc}\text { GO:0005125 } & \text { Cytokine activity } & 2.03 \mathrm{E}-08 \\ \text { GO:0005102 } & \text { Receptor binding } & 1.39 \mathrm{E}-07 \\ \text { GO:0008083 } & \text { Growth factor activity } & 1.07 \mathrm{E}-06 \\ \text { GO:0005515 } & \text { Protein binding } & 5.30 \mathrm{E}-05 \\ \text { GO:0042379 } & \text { Chemokine receptor binding } & 6.13 \mathrm{E}-05\end{array}$

\section{GO (Biological process)}

GO:0051094 Positive regulation of developmental process

2.49E-09

$\begin{array}{lll}\text { GO:0006954 Inflammatory response } & \text { 2.06E-08 }\end{array}$

GO:0048584 Positive regulation of response to stimulus 4.98E-08

$\begin{array}{lll}\text { GO:0009611 Response to wounding } & \text { 7.63E-08 }\end{array}$

GO:0009605 Response to external stimulus $1.64 \mathrm{E}-07$

\section{GO (Cellular component)}

$\begin{array}{lll}\text { GO:0005615 Extracellular space } & \text { 4.42E-16 }\end{array}$

GO:0005576 Extracellular region 3.55E-14

$\begin{array}{lll}\text { GO:0044421 Extracellular region part } & \text { 7.29E-14 }\end{array}$

\section{Pathway (SEA)}

WP385_72108 Mm Myometrial Relaxation and Contraction Pathway 8.01E-06

WP2604_73066 Mm Limb and Fin Development $\quad$ 8.88E-06

WP512_69147 Mm Id Signaling Pathway 1.90E-05

WP2292_72463 Mm Chemokine signaling pathway 2.55E-05

WP1270_72216 Mm Endochondral Ossification 4.94E-05

WP2589_72924 Mm Limb Development 2.72E-04

WP258_73847 Mm TGF-beta Receptor Signaling Pathway 4.27E-04

WP2309_72004 Mm XpodNet, protein-protein interaction in the podocyte $\quad 1.01 \mathrm{E}-03$ expanded by STRING 
WP2316_69143 Mm PPAR signaling pathway

1.85E-03

WP2310_72005 Mm PodNet, protein-protein interactions in the podocyte

4.29E-03

Kyoto Encyclopedia of Genes and Genomes (KEGG)

mmu04060 Cytokine-cytokine receptor interaction

4.15E-04

mmu05200

Pathways in cancer

1.10E-02

mmu04062

Chemokine signaling pathway

1.80E-02 


\section{GO (Molecular function)}

GO:0005125 Cytokine activity

3.85E-05

GO:0005179 Hormone activity

7.40E-03

GO:0008009 Chemokine activity

7.94E-03

GO:0042379 Chemokine receptor binding

8.34E-03

GO:0003924 GTPase activity

1.04E-02

\section{GO (Biological process)}

GO:0006955 Immune response

1.96E-06

GO:0006954 Inflammatory response

8.05E-05

GO:0006952 Defense response

8.18E-05

GO:0009611 Response to wounding

8.26E-04

GO:0043410

Positive regulation of MAPKKK cascade

1.01E-02

\section{GO (Cellular component)}

GO:0005615 Extracellular space

GO:0005576 Extracellular region

GO:0044421 Extracellular region part

\section{Pathway (SEA)}

WP2432_71041 Mm Spinal Cord Injury

3.28E-06

WP447_73875 Mm Adipogenesis genes

2.52E-04

WP1271_69089 Mm Toll-like receptor signaling pathway

1.40E-03

WP222_70944 Mm Cytokines and Inflammatory Response (BioCarta)

1.77E-03

WP385_72108 Mm Myometrial Relaxation and Contraction Pathways

5.66E-03

WP512_69147 Mm Id Signaling Pathway

6.20E-03

WP1266_69139 Mm SIDS Susceptibility Pathways

8.50E-03

WP2292_72463 Mm Chemokine signaling pathway

8.64E-03

WP1254_69153 Mm Apoptosis 
Kyoto Encyclopedia of Genes and Genomes

(KEGG)

mmu04060 Cytokine-cytokine receptor interaction

7.25E-04

mmu04621 NOD-like receptor signaling pathway

1.57E-02

mmu04620

Toll-like receptor signaling pathway

3.77E-02 